\title{
Carbon-emcoating architecture boosts lithium storage of $\mathrm{Nb}_{2} \mathrm{O}_{5}$
}

\author{
Qing Ji ${ }^{1,2 \dagger}$, Zhuijun $\mathrm{Xu}^{1,3 \dagger}$, Xiangwen $\mathrm{Gao}^{4,5 \dagger}$, Ya-Jun Cheng ${ }^{1,4^{*}}$, Xiaoyan Wang ${ }^{1}$, Xiuxia Zuo ${ }^{1}$, \\ George Z. Chen ${ }^{2,6}$, Binjie $\mathrm{Hu}^{2 *}$, Jin Zhu ${ }^{1}$, Peter G. Bruce ${ }^{4,7,8}$ and Yonggao Xia ${ }^{1,9^{*}}$
}

\begin{abstract}
Intercalation transition metal oxides (ITMO) have attracted great attention as lithium-ion battery negative electrodes due to high operation safety, high capacity and rapid ion intercalation. However, the intrinsic low electron conductivity plagues the lifetime and cell performance of the ITMO negative electrode. Here we design a new carbon-emcoating architecture through single $\mathrm{CO}_{2}$ activation treatment as demonstrated by the $\mathrm{Nb}_{2} \mathrm{O}_{5} / \mathrm{C}$ nanohybrid. Triple structure engineering of the carbon-emcoating $\mathrm{Nb}_{2} \mathrm{O}_{5} / \mathrm{C}$ nanohybrid is achieved in terms of porosity, composition, and crystallographic phase. The carbon-embedding $\mathrm{Nb}_{2} \mathrm{O}_{5} / \mathrm{C}$ nanohybrids show superior cycling and rate performance compared with the conventional carbon coating, with reversible capacity of $387 \mathrm{~mA} \mathrm{~h} \mathrm{~g}$ at $0.2 \mathrm{C}$ and $92 \%$ of capacity retained after 500 cycles at $1 \mathrm{C}$. Differential electrochemical mass spectrometry (DEMS) indicates that the carbon emcoated $\mathrm{Nb}_{2} \mathrm{O}_{5}$ nanohybrids present less gas evolution than commercial lithium titanate oxide during cycling. The unique carbon-emcoating technique can be universally applied to other ITMO negative electrodes to achieve high electrochemical performance.
\end{abstract}

Keywords: niobium pentoxide/carbon nanohybrids, mesoporous, $\mathrm{CO}_{2}$ activation, emcoating, lithium-ion battery negative electrode

\section{INTRODUCTION}

Intercalation transition metal oxides (ITMO) appeal to researchers as alternatives for negative electrodes of li- thium-ion battery due to their high theoretical capacity, high redox potential, and low volume change [1,2]. However, intrinsic low electric conductivity restricts the rate performance and further practical application of ITMO. Great efforts on constructing nanostructured ITMO have proved that size reduction is an effective method to shorten the Li-ion diffusion length and offer better accessibility for the electrolyte [3]. However, the low electron conductivity issue remains. Compositing nanostructured ITMO with carbon matrix is a promising strategy to achieve enhanced rate performance and the carbon matrix could stabilize the ITMO nanoscale structure simultaneously during lithium ion insertion/ extraction [4]. In general, carbon coating and carbon embedding are two conventional strategies to integrate ITMO with carbon [5-10]. However, the typical carbon coating tends to proceed only on the outer surface of ITMO because the carbon source can hardly access the interior region of the agglomerate. Methods such as coreshell structure construction allow enhanced carbon coating; however, convoluted process is normally involved [5]. Besides, the core-shell structure still retains individual nanoparticulate feature, which could bring adverse effects such as inferior tap density [11]. Compared with the coating method, the carbon-embedding offers continuous carbon wrapping on the total surface of ITMO $[10,12,13]$. Micro-/nano-scale hierarchical architectures can be built based on the embedding method. As

\footnotetext{
${ }^{1}$ Ningbo Institute of Materials Technology and Engineering, Chinese Academy of Sciences, Ningbo 315201, China

2 The University of Nottingham Ningbo China, Ningbo 315100, China

${ }^{3}$ University of Chinese Academy of Sciences, Beijing 100049, China

${ }^{4}$ Department of Materials, University of Oxford, Parks Rd, OX1 3PH, Oxford, United Kingdom

${ }^{5}$ Materials Science and Engineering Program and Texas Materials Institute, University of Texas at Austin, Austin, TX 78712, USA

${ }^{6}$ University of Nottingham, University Park, Nottingham NG7 2RD, United Kingdom

${ }^{7}$ The Henry Royce Institute, Parks Road, Oxford OX1 3PH, United Kingdom

${ }^{8}$ The Faraday Institution, Quad One, Becquerel Avenue, Harwell Campus, Didcot OX11 OR1, United Kingdom

${ }^{9}$ Center of Materials Science and Optoelectronics Engineering, University of Chinese Academy of Sciences, Beijing 100049, China

† These authors contributed equally to this work.

* Corresponding authors (emails: chengyj@nimte.ac.cn (Cheng YJ); binjie.hu@nottingham.edu.cn (Hu B); xiayg@nimte.ac.cn (Xia Y))
} 
a result, side effects originating from the nano-sized structure feature can be circumvented [14].

Our group has developed a new concept to embed nanoscale ITMO $\left(\mathrm{NbO}_{2}, \mathrm{Nb}_{2} \mathrm{O}_{5}, \mathrm{TiO}_{2}\right.$ and $\left.\mathrm{Li}_{4} \mathrm{Ti}_{5} \mathrm{O}_{12}\right)$ in carbon matrix using dimethacrylate-based dental resin monomer as the solvent and carbon source over the past few years [15-19]. Metal ions are incorporated into the polymer network during the curing process where the dental resin monomer reacts with the ITMO precursors. Thus, super-small metal oxide nanoparticles are in situ generated and embedded in the carbon matrix homogeneously during the carbonization process. The as-prepared metal oxide/carbon nanohybrids present high tap density and unique electrochemical performance. However, a few critical issues remain. High content of dense structured carbon prevents the wetting of the electrolyte to access the ITMO within the carbon matrix, where electrochemical kinetics is retarded, and apparent electrochemical performance is compromised. Besides, excessive carbon matrix is generated surrounding the ITMO nanoparticle, which makes significant contribution to the overall capacity while the intrinsic electrochemical performance of ITMO is smeared [20-22]. Furthermore, the in situ formed carbon matrix suppresses the growth of metal oxide nanocrystal, which yields poor crystallinity and short lithiation plateau. As a result, the characteristic lithiation/delithiation profiles are deviated and the complexity of battery management is increased in practical applications.

Here, a unique emcoating concept is developed to perform carbon compositing with the nanostructured ITMO, which combines the advantages of both coating and embedding methods, while the drawbacks are avoided. Carbon emcoated $\mathrm{Nb}_{2} \mathrm{O}_{5}$ nanohybrids are constructed through facile scalable one-step carbon dioxide $\left(\mathrm{CO}_{2}\right)$ activation of the $\mathrm{Nb}_{2} \mathrm{O}_{5} / \mathrm{C}$ nanohybrid with the embedding structure feature. Triple structure engineering including carbon content modification, porosity tuning, and crystallographic phase manipulation of the $\mathrm{Nb}_{2} \mathrm{O}_{5} / \mathrm{C}$ emcoating nanohybrid is achieved. This strategy possesses several distinct advantages. First, excessive carbon is etched, and thin carbon coating is formed on the surface of each individual $\mathrm{Nb}_{2} \mathrm{O}_{5}$ nanoparticle, while the continuous electron conductive network remains. The shortened pathway from electrolyte to the $\mathrm{Nb}_{2} \mathrm{O}_{5}$ nanoparticle enables accelerated lithium ion diffusion, leading to enhanced electrochemical kinetics and improved rate performance. Second, the $\mathrm{Nb}_{2} \mathrm{O}_{5}$ nanoparticles are still homogeneously distributed within the micrometer-scale continuous conductive carbon matrix inherited from the embedding structure. The agglomeration of the $\mathrm{Nb}_{2} \mathrm{O}_{5}$ nanoparticles is suppressed, where individual $\mathrm{Nb}_{2} \mathrm{O}_{5}$ nanoparticles can effectively participate in the lithiation process. Besides, the homogeneous dispersion of the $\mathrm{Nb}_{2} \mathrm{O}_{5}$ nanoparticles within the carbon matrix helps to relief mechanical stress upon lithiation, leading to improved cyclic stability. Third, compared with conventional activation methods such as hot air and $\mathrm{KOH}$ treatments, $\mathrm{CO}_{2}$ activation is regarded as mild, controllable, facile, free of post-treatment, and easy to scaleup, which is particularly attractive for practical applications. Consequently, the construction of the emcoating structure within the $\mathrm{Nb}_{2} \mathrm{O}_{5} / \mathrm{C}$ nanohybrid endows superior cycling stability and rate capability. Comprehensive studies on the fundamental mechanism for emcoating structure construction, phase transition of $\mathrm{Nb}_{2} \mathrm{O}_{5}$ during structure evolution, and structure-property correlation of the $\mathrm{Nb}_{2} \mathrm{O}_{5} / \mathrm{C}$ emcoating nanohybrid are carried out in this study.

\section{EXPERIMENTAL SECTION}

\section{Materials}

Niobium (V) ethoxide (NbETO) was purchased from Alfa Aesar Co., Ltd. Bisphenol A-glycidyl methacrylate (Bis-GMA) and tert-butyl peroxy benzoate (TBPB) were obtained from Sigma-Aldrich. Poly(vinylidene fluoride) (PVDF) was donated by Solvay. Conductive carbon black (Super P) was purchased from SCM Chem, Shanghai. $N$ methyl pyrrolidone (NMP) was acquired from Aladdin Reagent Co., Ltd. All chemicals were used as received.

\section{Sample preparation}

The pristine embedding type $\mathrm{Nb}_{2} \mathrm{O}_{5} / \mathrm{C}$ nanohybrids were prepared according to our previous work with the BisGMA/NbETO mass ratio of 1:1 [18]. The carbon-emcoating samples were prepared with further heat treatment at $900^{\circ} \mathrm{C}$ under $\mathrm{CO}_{2}$ atmosphere with a flow rate of $0.5 \mathrm{~L} \mathrm{~min}^{-1}$ for $1 \mathrm{~h}$. To study the mechanism responsible for the structure evolution during $\mathrm{CO}_{2}$ heat treatment, the pristine samples were treated with $\mathrm{CO}_{2}$ at $900^{\circ} \mathrm{C}$ for $2 \mathrm{~h}$ and $800^{\circ} \mathrm{C}$ for 1 and $2 \mathrm{~h}$ as well.

\section{Material characterization}

$\mathrm{X}$-ray diffractometer (XRD; Bruker AXS D8 Advance, $\lambda=$ $1.5406 \AA 2.2 \mathrm{~kW}$ ) was applied to identify the crystallographic phases of the niobium oxide/carbon nanohybrids and $\mathrm{CO}_{2}$-activated samples with $2 \theta$ from $5^{\circ}$ to $90^{\circ}$. $\mathrm{X}$-ray photoelectron spectroscopy (XPS) measurements were performed on an ESCALAB 250 XI model spec- 
trometer with $\mathrm{Al} \mathrm{Ka}$ radiation $(h v=1486.6 \mathrm{eV})$. Scanning electron microscope (SEM; Hitachi S4800) was used to characterize the morphology at an accelerating voltage of $4 \mathrm{kV}$. The carbon content was measured by a Mettler Toledo thermos-gravimetric analyzer (TGA) with a temperature range from 50 to $800^{\circ} \mathrm{C}$ at a ramp rate of $20^{\circ} \mathrm{C} \mathrm{m^{-1 }}$ in air. Phase structure of the niobium oxide/ carbon nanohybrids was determined by Raman spectroscopy (Renishaw, in Via-reflex). A JEOL JEM-2100F transmission electron microscope (TEM) was adopted for high-resolution imaging and selected area electron diffraction (SAED). Specimens for TEM were prepared by sonicating the $\mathrm{Nb}_{2} \mathrm{O}_{5} / \mathrm{C}$ powders in ethanol for $10 \mathrm{~min}$, which were then dropped onto a copper grid and dried by an infrared lamp. A Micromeritics ASAP2020 was applied to characterize the Brunauer-Emmett-Teller (BET) surface area and pore size distribution profile with $\mathrm{N}_{2}$ adsorption isotherms at $77 \mathrm{~K}$.

\section{Electrochemical measurement}

The electrochemical performance was evaluated using CR-2032 type coin cells in a half-cell configuration. Electrodes were prepared by manual mixing of the nanohybrid material, super $\mathrm{P}$ and PVDF in a mortar with a mass ratio of $8: 1: 1$, where NMP was used as the dispersion medium. The mixture was then cast onto copper foil and dried at $80^{\circ} \mathrm{C}$ for $4 \mathrm{~h}$. Typical electrode presented a mass density between 2 and $3 \mathrm{mg} \mathrm{cm}^{-2}$. Coin cells were assembled with lithium metal foil (Dongguan Shanshan battery Materials Co., LTD) and Celgard 2400 microporous polypropylene membrane as counter electrode and separator, respectively, in argon-filled glove box. Electrolyte from Zhangjiagang Guotai-Huarong Commercial New Material Co., LTD was adopted, with $1.0 \mathrm{~mol} \mathrm{~L}^{-1} \mathrm{LiPF}_{6}$ dissolved in a solution mixture of ethylene carbonate (EC), dimethyl carbonate (DMC) and fluoroethylene carbonate (EC:DMC=1:1 by volume, FEC $5 \%$ by mass). A Neware Battery Test System was employed to conduct galvanostatic cycling and rate tests at a voltage range from 0.01 to $3.0 \mathrm{~V}$ (versus $\mathrm{Li}^{+} / \mathrm{Li}$ ) and from 1.0 to $3.0 \mathrm{~V}$ (versus $\mathrm{Li}^{+} / \mathrm{Li}$ ). A current rate of $1 \mathrm{C}$ was set as $200 \mathrm{~mA} \mathrm{~g}^{-1}$. A Solartron Analytical electrochemical workstation was used for cyclic voltammetry (CV, 0.001$3.0 \mathrm{~V}, 0.2 \mathrm{mV} \mathrm{s}^{-1}$ ) and the electrochemical impedance spectroscopy (EIS, $0.001 \mathrm{HZ}-1 \mathrm{MHz}, 10 \mathrm{mV}$ ) measurements. The galvanostatic intermittent titration technique (GITT) test was carried out on a Neware Battery Test System. The battery was discharged and charged with a small pulse current at $20 \mathrm{~mA} \mathrm{~g}^{-1}$ for $10 \mathrm{~min}$ followed by a rest period of $30 \mathrm{~min}$ at a potential from 0.01 to $3.0 \mathrm{~V}$.

Differential electrochemical mass spectrometry (DEMS) was conducted according to previously reports [23-25]. Measurements were conducted with Swagelok type cell. Argon with a flow rate of $0.5 \mathrm{ml} \mathrm{min}{ }^{-1}$ was applied as conveying gas to flush out the gas generated.

\section{RESULTS AND DISCUSSION}

Fig. 1 schematically illustrates the structural evolution from embedding to emcoating of the $\mathrm{Nb}_{2} \mathrm{O}_{5}$ /carbon nanohybrids through the $\mathrm{CO}_{2}$ activation process [26,27]. The $\mathrm{Nb}_{2} \mathrm{O}_{5}$ nanoparticles of the pristine sample are fully embedded in the dense carbon matrix. With $\mathrm{CO}_{2}$ acti-

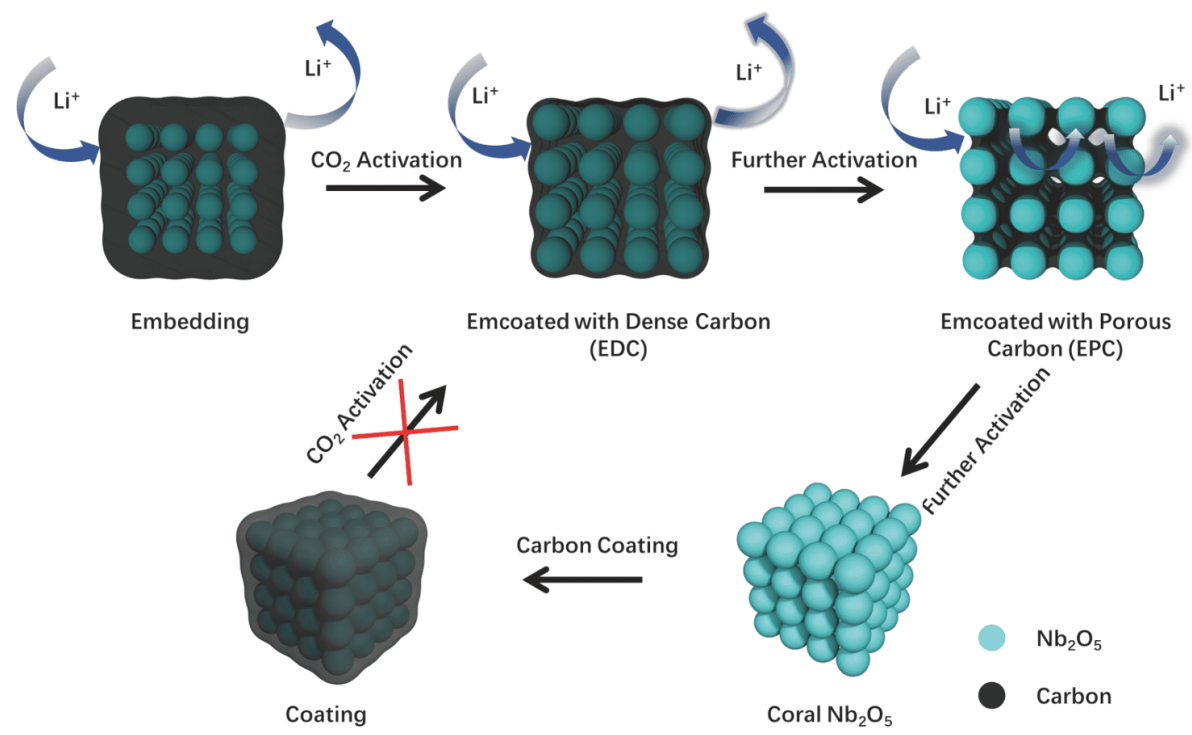

Figure 1 Schematic illustration of the $\mathrm{Nb}_{2} \mathrm{O}_{5}$ /carbon nanohybrid structure evolution from embedding to emcoating. 
vation, the dense carbon matrix is partially etched first, while the spatial distribution status of the $\mathrm{Nb}_{2} \mathrm{O}_{5}$ nanoparticles remains intact. $\mathrm{CO}_{2}$ only etches the surface of carbon matrix; the inner carbon keeps its dense structure, and this carbon composition state is noted as $\mathrm{Nb}_{2} \mathrm{O}_{5}$ emcoated with dense carbon (emcoating with dense carbon, abbreviated as EDC). With further $\mathrm{CO}_{2}$ activation, the outer surface of the $\mathrm{Nb}_{2} \mathrm{O}_{5}$ particles has no carbon coating anymore (defined as exterior region). However, the inner carbon matrix is only partially etched and thin coating layer is retained on the inner surface of the $\mathrm{Nb}_{2} \mathrm{O}_{5}$ particles (defined as interior region). This thin carbon coating on the inner surface of each $\mathrm{Nb}_{2} \mathrm{O}_{5}$ particle is connected and continuous carbon network is therefore preserved. The thin carbon coating layer tends to be porous because of extensive $\mathrm{CO}_{2}$ activation. Thus, the sample presenting emcoating structure with thin, porous and interconnected carbon coating is fabricated (emcoating with porous carbon, abbreviated as EPC).

From a structure model perspective, both the EDC and EPC structures can be defined as following. EDC: Full carbon coating particles inter-connected by dense carbon matrix. Within this structure, any two arbitrary points at the surface of the $\mathrm{Nb}_{2} \mathrm{O}_{5}$ particle can be connected by at least one route throughout the carbon matrix. In actual material systems, tremendous amount of points at the particle surface are connected by at least one route throughout the carbon matrix. The particles are fully covered by carbon, which are further connected by carbon matrix. Because the carbon matrix is not etched, it retains a dense structure. EPC: Partial carbon coating particles inter-connected by porous carbon matrix. In actual material systems, the carbon coating at the surface of the particles is partially removed, leaving part of the particle surface naked. Meanwhile, the carbon matrix of inter-connecting neighbouring particles becomes porous due to partial carbon removal. Exterior region of the EPC: Carbon-free region on the surface of the particles within the EPC. Inside this specific region, any two arbitrary points at the surface of the $\mathrm{Nb}_{2} \mathrm{O}_{5}$ particles cannot be connected by a route throughout the carbon matrix. In actual material systems, this region may have some small areas still covered by residual carbon. However, it is generally defined as the exterior region of the EPC for the reason of simplicity. Interior region of the EPC: Carbon remaining region within the EPC. In this specific region, there are at least two points at the surface of the $\mathrm{Nb}_{2} \mathrm{O}_{5}$ particles connected by at least one route throughout the carbon matrix. However, in actual material systems, tremendous amount of points are connected by at least one route throughout the carbon matrix.

Compared with the pristine embedding structure, the emcoating structure bears a good conductivity with less carbon content. Additionally, the EPC structured $\mathrm{Nb}_{2} \mathrm{O}_{5} /$ $\mathrm{C}$ nanohybrid provides enhanced accessibility towards electrolyte and shorter Li-ion transportation path for $\mathrm{Nb}_{2} \mathrm{O}_{5}$ nanoparticles than the EDC structure as interpreted by the sketch in Fig. 1 .

Coral structured $\mathrm{Nb}_{2} \mathrm{O}_{5}$ will be generated by further enhanced $\mathrm{CO}_{2}$ activation with extended time or elevated temperature (for example, at $900^{\circ} \mathrm{C}$ ), where carbon matrix is fully eliminated, and naked $\mathrm{Nb}_{2} \mathrm{O}_{5}$ nanoparticles start to agglomerate. Carbon coating can be further formed onto the coral $\mathrm{Nb}_{2} \mathrm{O}_{5}$ by different methods such as chemical vapor deposition (CVD) and mechanical ballmilling. However, the carbon coating can only proceed at the outer surface of the coral structured $\mathrm{Nb}_{2} \mathrm{O}_{5}$, where the interior region is difficult to be coated. It is impossible to build the emcoating structure via $\mathrm{CO}_{2}$ activation treatment of the carbon-coated coral $\mathrm{Nb}_{2} \mathrm{O}_{5}$ particulate agglomerate. Electron conductivity improvement from carbon coating is not as efficient as that from the emcoating structure.

The actual structure evolution of the $\mathrm{Nb}_{2} \mathrm{O}_{5} / \mathrm{C}$ nanohybrid from embedding to emcoating induced by $\mathrm{CO}_{2}$ activation is characterized by SEM and TEM (Fig. 2 and Fig. S1). The pristine carbon-embedded $\mathrm{Nb}_{2} \mathrm{O}_{5}$ nanohybrids present a dense bulk structure with a smooth surface, particle size ranging from 1 to $5 \mu \mathrm{m}$ (Fig. 2a-1). Upon $\mathrm{CO}_{2}$ activation at $800^{\circ} \mathrm{C}$, the $\mathrm{Nb}_{2} \mathrm{O}_{5}$ nanoparticles grow from $5 \mathrm{~nm}$ (Fig. 2a-2) to $20-50 \mathrm{~nm}$ (Fig. 2b-2). High-resolution TEM (HRTEM) and SAED images show a clear phase transition from hexagonal phase in the pristine (Fig. 2a-3, a-4) to the orthorhombic phase (Fig. $2 \mathrm{~b}-3, \mathrm{~b}-4)$. The surface of the EDC structured $\mathrm{Nb}_{2} \mathrm{O}_{5} / \mathrm{C}$ nanohybrid becomes porous and rough with some nanoparticles exposed at the surface due to consumption of carbon by $\mathrm{CO}_{2}$ (Fig. 2b-1). It proves that only slight surface activation occurs at $800^{\circ} \mathrm{C}$, consistent with previously reported papers [28-31]. After further treatment at $900^{\circ} \mathrm{C}$, small pores are generated at the surface of the EPC structured $\mathrm{Nb}_{2} \mathrm{O}_{5}$ (Fig. 2c-1). A bimodal particle size distribution is observed with the EPC structured $\mathrm{Nb}_{2} \mathrm{O}_{5}$, which are $15-20 \mathrm{~nm}$ and $50-100 \mathrm{~nm}$, respectively (Fig. 2c-2). HRTEM images (Fig. 2c-3, c-4) confirm that the small crystal refers to the orthorhombic $\mathrm{Nb}_{2} \mathrm{O}_{5}$ and the large one refers to the monoclinic $\mathrm{Nb}_{2} \mathrm{O}_{5}$. In addition, the EPC sample shows more porous structure inside the carbon matrix, consistent with the surface morphology revealed by the SEM images. With further activation time, 

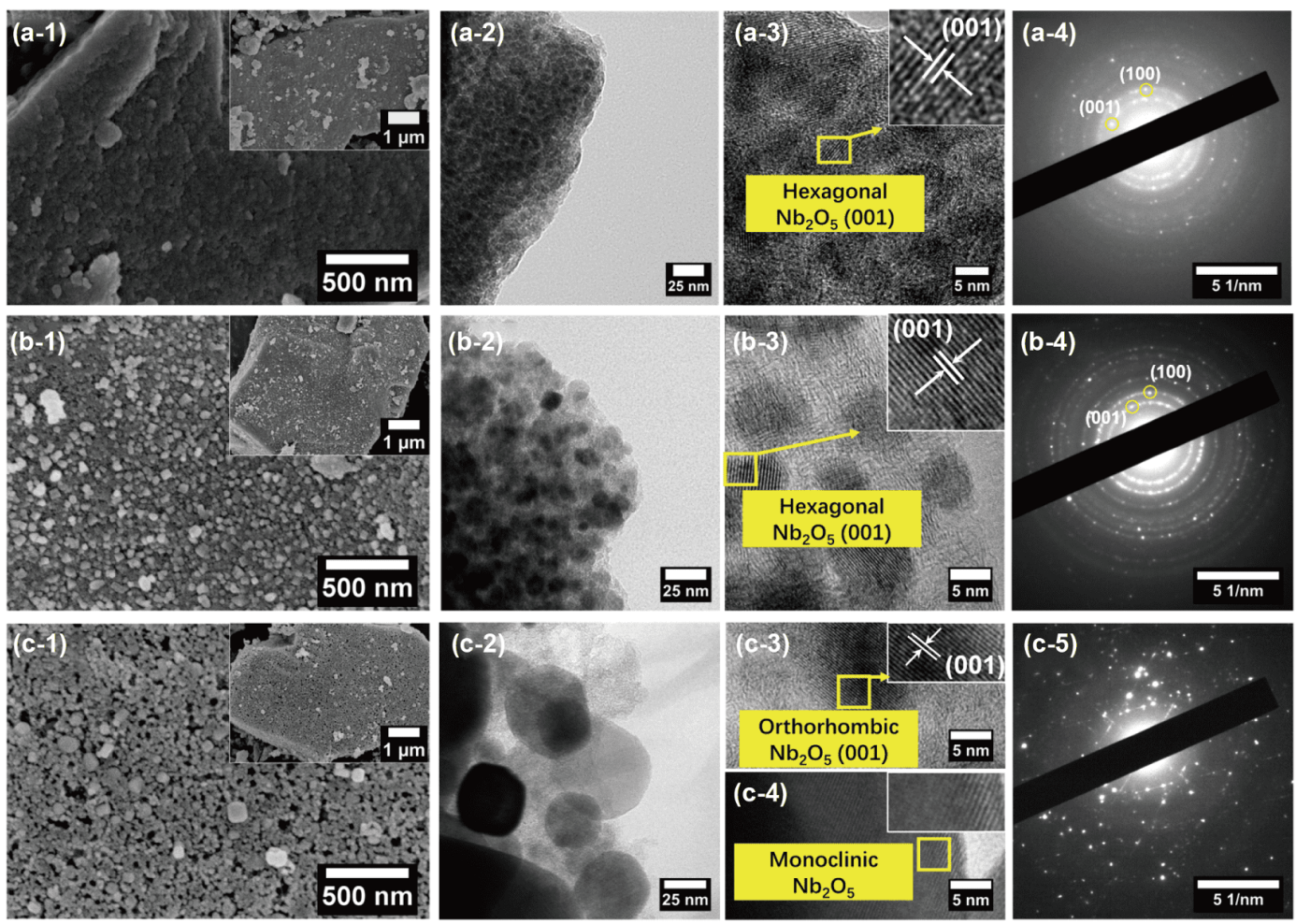

Figure 2 Structure evolution of the $\mathrm{Nb}_{2} \mathrm{O}_{5} / \mathrm{C}$ nanohybrid from pristine $\mathrm{Nb}_{2} \mathrm{O}_{5}$ embedded with carbon (a) to emcoated with dense carbon (EDC, activated at $800^{\circ} \mathrm{C}$ for $2 \mathrm{~h}$ ) (b), and to emcoated with porous carbon (EPC, activated at $900^{\circ} \mathrm{C}$ for $1 \mathrm{~h}$ ) (c) induced by the $\mathrm{CO}_{2}$ activation. Image details: SEM (a-1, b-1, and c-1), TEM (a-2, b-2, and c-2), HRTEM (a-3, b-3, c-3, and c-4), and SAED (a-4, b-4, and c-5). Insets in a-1, b-1, and c-1: low magnification SEM images of the $\mathrm{Nb}_{2} \mathrm{O}_{5} / \mathrm{C}$ nanohybrids.

coral structured $\mathrm{Nb}_{2} \mathrm{O}_{5}$ is presented (Fig. S1a-1). The grain size grows to $100 \mathrm{~nm}$ and the crystallographic phase is fully transferred to the monoclinic $\mathrm{Nb}_{2} \mathrm{O}_{5}$ (Fig. S1b), confirmed by the diffraction patterns from the SAED result. The microscopic structure characterization illustrates that the carbon matrix evolves from dense bulk to porous and interconnected structure due to $\mathrm{CO}_{2}$ activation, while the spatial distribution of the $\mathrm{Nb}_{2} \mathrm{O}_{5}$ nanoparticles remains intact within the carbon matrix.

To further gain insights about the interior carbon distribution of the emcoating structure, a simulation model was established to estimate surface area contribution proportion from different regions of the $\mathrm{Nb}_{2} \mathrm{O}_{5}$ nanoparticulate agglomerate (Fig. 3). Based on the actual size revealed by the microscopic images, the nanoparticulate agglomerate is approximated as a cube with a length of $5.5 \mu \mathrm{m}$, built by packing the nanoparticles with a diameter of $7.8 \mathrm{~nm}$. The simulation model demonstrates that the inner surface provided by the particles contributes more than $99.7 \%$ of the total surface area; while the outer surface area accounts for only $0.3 \%$ of the total surface area. The simulation results suggest that the emcoating

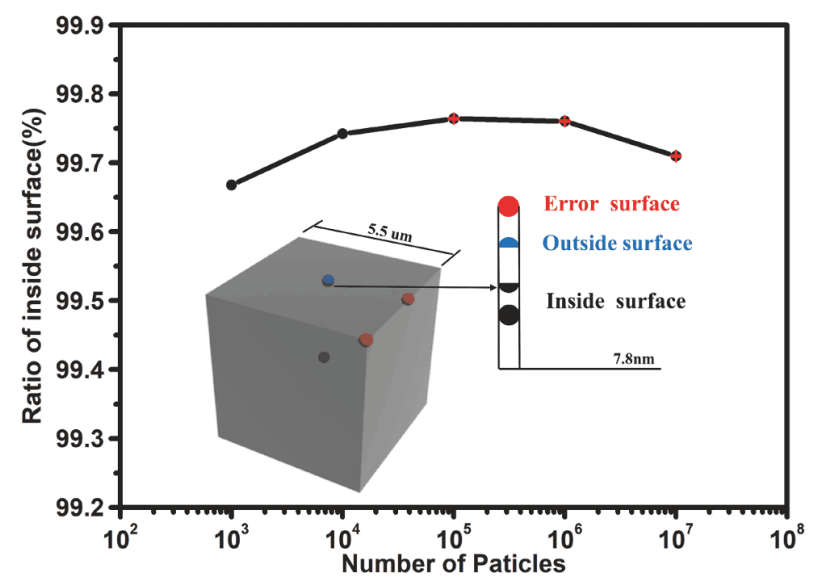

Figure 3 Simulation model of the nanoparticulate powder for inner and outer surface area distribution estimation. Grey cube: bulk shape of the $\mathrm{Nb}_{2} \mathrm{O}_{5}$ nanoparticulate agglomerate. Black sphere: inside part of the $\mathrm{Nb}_{2} \mathrm{O}_{5}$ particles. Blue sphere: outside part of the $\mathrm{Nb}_{2} \mathrm{O}_{5}$ particles. Red sphere: $\mathrm{Nb}_{2} \mathrm{O}_{5}$ particles on the edge of cube.

strategy enables carbon coating on the majority of the surface area of the nanoparticulate agglomerate. While the conventional carbon coating can only coat the outer 
surface area, which is only a tiny portion of the total surface area. Compared with the conventional surface coating method, the emcoating strategy holds a great potential to improve the electrochemical kinetics and rate capability by coating carbon onto the inner surface of the nanoparticulate agglomerate.

Carbon contents of the $\mathrm{Nb}_{2} \mathrm{O}_{5} / \mathrm{C}$ nanohybrids were determined by thermo gravimetric analyzer (TGA). Fig. 4a and Fig. S2a indicate that the carbon content decreases when the structure changes from embedding to emcoating after the $\mathrm{CO}_{2}$ activation. In addition, both increasing activation temperature and elongated activation time reduce the carbon content: the carbon etching process at $900^{\circ} \mathrm{C}$ is much stronger than that at $800^{\circ} \mathrm{C}$ and the carbon component is fully removed when the sample is processed at $900^{\circ} \mathrm{C}$ for $2 \mathrm{~h}$. To be precise, the pristine embedding type $\mathrm{Nb}_{2} \mathrm{O}_{5} / \mathrm{C}$ nanohybrid presents the carbon content of $40 \%$, while the carbon contents of the EDC, EPC and coral $\mathrm{Nb}_{2} \mathrm{O}_{5}$ are $27 \%, 8 \%$ and $0 \%$, respectively (Table $\mathrm{S} 1$ ). Both the pristine and $\mathrm{CO}_{2}$-activated samples present characteristic peaks of disordered carbon (D-band) at $1360 \mathrm{~cm}^{-1}$ and graphitic carbon (G-band) at
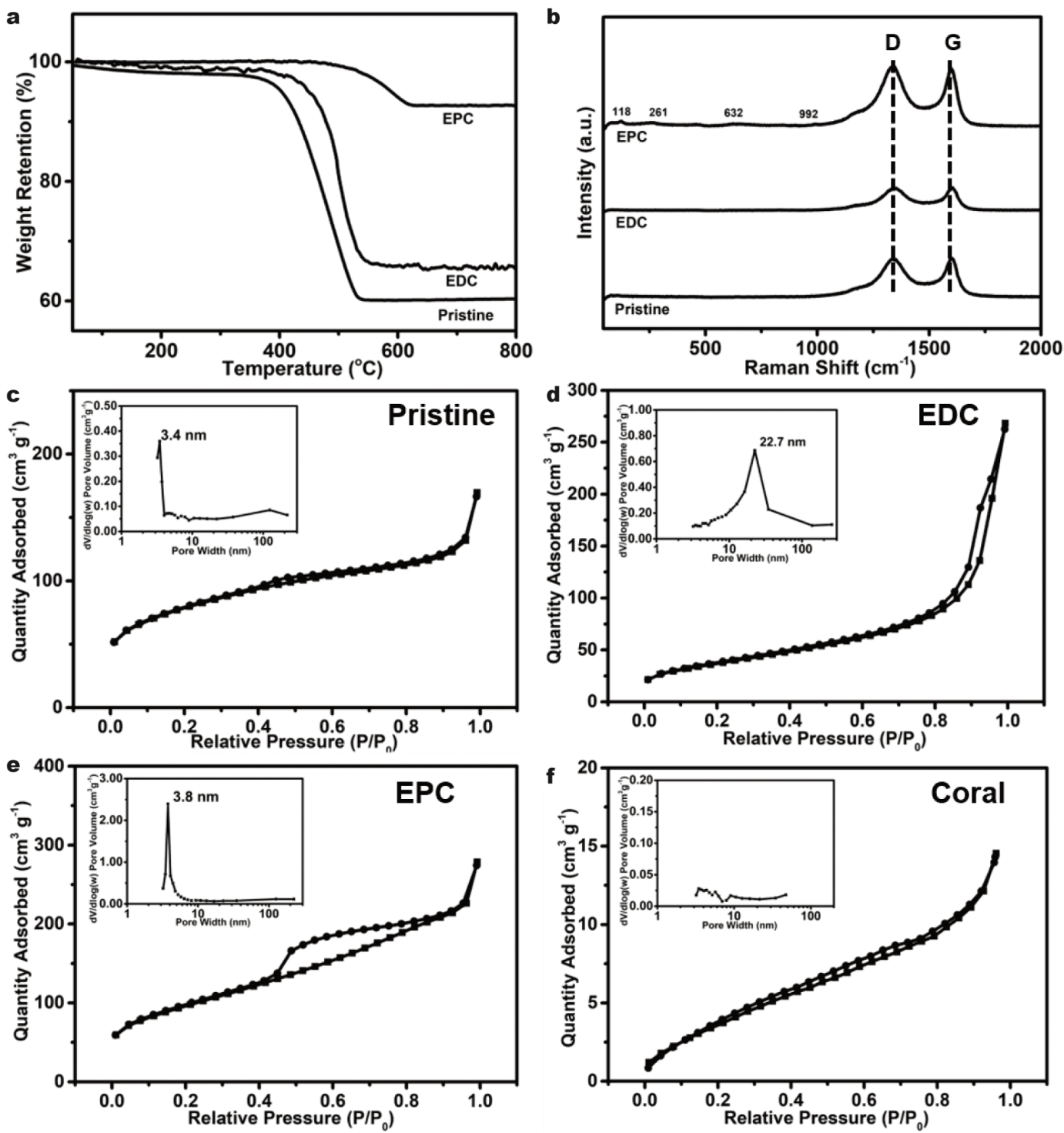

Figure 4 Structure characterizations of the $\mathrm{Nb}_{2} \mathrm{O}_{5} / \mathrm{C}$ nanohybrids with carbon embedding (pristine), EDC, and EPC. Thermogravimetric profiles (a) and Raman spectroscopy (b) of the pristine, embedded, and emcoated $\mathrm{Nb}_{2} \mathrm{O}_{5} ; \mathrm{N}_{2}$ adsorption/desorption isotherms (inset: corresponding BarrettJoyner-Halenda $(\mathrm{BJH})$ pore size distribution curves) of the pristine embedded $\mathrm{Nb}_{2} \mathrm{O}_{5}(\mathrm{c}), \mathrm{EDC}$ structured $\mathrm{Nb}_{2} \mathrm{O}_{5} / \mathrm{C}(\mathrm{d}), \mathrm{EPC}$ structured $\mathrm{Nb}_{2} \mathrm{O}_{5} / \mathrm{C}(\mathrm{e})$ and coral $\mathrm{Nb}_{2} \mathrm{O}_{5}$ (f). 
$1590 \mathrm{~cm}^{-1}$ in the Raman spectra (Fig. 4b). Although the coral structured $\mathrm{Nb}_{2} \mathrm{O}_{5}$ displays no carbon content from the TGA result, trace amount of carbon contributes to the characteristic peaks (Fig. S2b). The integrative intensity ratio of the $\mathrm{D}$ band and the $\mathrm{G}$ band $\left(I_{\mathrm{D}} / I_{\mathrm{G}}\right)$ refers to the extent of disordered carbon (Table $\mathrm{S} 1$ ). The $I_{\mathrm{D}} / I_{\mathrm{G}}$ value decreases with increasing activation temperature, which indicates higher graphitization after activation [32,33]. In addition, with activation under $900^{\circ} \mathrm{C}$, small peaks appear at fingerprints region, and the coral structured $\mathrm{Nb}_{2} \mathrm{O}_{5}$ bears strong peaks at $118,261,632$ and $992 \mathrm{~cm}^{-1}$ originating from the $\mathrm{Nb}_{2} \mathrm{O}_{5}$ phase [34]. The increasing peak intensity of the $\mathrm{Nb}_{2} \mathrm{O}_{5}$ is assigned to the particle growth and enhanced crystallization, consistent with the TEM images [35].

BET measurements investigated the porosity evolution of the $\mathrm{Nb}_{2} \mathrm{O}_{5} / \mathrm{C}$ nanohybrids along with different $\mathrm{CO}_{2}$ activation treatments (Fig. $4 \mathrm{c}-\mathrm{f}$ ). The pristine carbonembedded $\mathrm{Nb}_{2} \mathrm{O}_{5}$ presents type I adsorption/desorption isotherms, referring to a microporous structure (Fig. 4c). After $\mathrm{CO}_{2}$ activation, typical type IV isotherms are observed in the EDC and EPC structured $\mathrm{Nb}_{2} \mathrm{O}_{5}$, and the pore size distribution shifts to $3.8 \mathrm{~nm}$ (EPC structured $\mathrm{Nb}_{2} \mathrm{O}_{5}$ ) and $20 \mathrm{~nm}$ (EDC structured $\mathrm{Nb}_{2} \mathrm{O}_{5}$ ), confirming the presence of mesoporous structure (Fig. $4 \mathrm{~d}$, e) [36]. Note that $\mathrm{CO}_{2}$ activation would generate micropores on the surface of carbon matrix, and thus slight pore size increase is detected $[28,29]$. The coral $\mathrm{Nb}_{2} \mathrm{O}_{5}$ possesses the type II isotherms with a non-porous structure (Fig. S2d). As the porous structure is mostly contributed by the carbon content in the nanohybrid, the pores vanish due to full removal of the carbon component by $\mathrm{CO}_{2}$. Assisted by the strong pore generation effect of $\mathrm{CO}_{2}$ activation under $900^{\circ} \mathrm{C}$, the EPC structured $\mathrm{Nb}_{2} \mathrm{O}_{5}$ presents a substantial increase of BET surface area from 57.7 to $221 \mathrm{~m}^{2} \mathrm{~g}^{-1}$ (Table S2). While the EDC structured $\mathrm{Nb}_{2} \mathrm{O}_{5}$ shows only a minor increase of the surface area due to less extent of the $\mathrm{CO}_{2}$ activation at a low temperature.

XRD was applied to investigate the crystallographic phase change of the $\mathrm{Nb}_{2} \mathrm{O}_{5} / \mathrm{C}$ nanohybrids induced by the $\mathrm{CO}_{2}$ activation (Fig. 5a, b). Compared with the pristine carbon embedding $\mathrm{Nb}_{2} \mathrm{O}_{5} / \mathrm{C}$ nanohybrid, the diffraction peaks of both the EDC and EPC samples become sharper, showing enhanced crystallization of the $\mathrm{Nb}_{2} \mathrm{O}_{5}$ nanoparticles through the $\mathrm{CO}_{2}$ activation process, consistent with the TEM results. In addition, different crystallographic phases are observed with the $\mathrm{CO}_{2}$ activation at 800 and $900^{\circ} \mathrm{C}$. The pristine carbon embedding $\mathrm{Nb}_{2} \mathrm{O}_{5} / \mathrm{C}$ nanohybrid presents a typical hexagonal phase (JCPDS No. 28-0317) (Fig. 5a); while the EDC structured $\mathrm{Nb}_{2} \mathrm{O}_{5} /$
C shows a splitting peak at $28^{\circ}$, implying a transformation from hexagonal phase to orthorhombic phase (JCPDS No. 27-1003). When the activation temperature increases to $900^{\circ} \mathrm{C}$, the EPC structured $\mathrm{Nb}_{2} \mathrm{O}_{5} / \mathrm{C}$ presents further phase transition from pure hexagonal phase to bi-phase of orthorhombic/monoclinic (Fig. 5b) with the quantities of the orthorhombic and monoclinic of $43.1 \%$ and $56.9 \%$, respectively, based on a reference intensity ratio (RIR) method [37]. Generally, the phase transition of $\mathrm{Nb}_{2} \mathrm{O}_{5}$ from hexagonal to monoclinic depends on the annealing temperature (Table 1). Although the pristine sample is synthesized at $900^{\circ} \mathrm{C}$, the dense-structured carbon matrix can introduce carbon doping into the $\mathrm{Nb}_{2} \mathrm{O}_{5}$ nanoparticles, which hinders the phase transition from hexagonal to orthorhombic/monoclinic under $900^{\circ} \mathrm{C}$. Such obstruction effect by the doped carbon has been revealed in the $\mathrm{TiO}_{2}$ phase transition [38-41]. During the $\mathrm{CO}_{2}$ activation process, the carbon matrix is etched gradually, which partially eliminates the doped carbon and facilitates phase transition.

In order to understand the mechanism governing the phase transition of $\mathrm{Nb}_{2} \mathrm{O}_{5}$ induced by the $\mathrm{CO}_{2}$ activation, XPS was applied to detect the valence state and chemical environment of the $\mathrm{Nb}_{2} \mathrm{O}_{5}$ nanoparticles. The XPS spectra (Fig. 5d-f and Fig. S3) confirm the existence of carbon, oxide and niobium on the surface of the $\mathrm{Nb}_{2} \mathrm{O}_{5} / \mathrm{C}$ nanohybrid. Peaks assigned to the binding energies of 287.5 and $288.5 \mathrm{eV}$ are observed in the high resolution $\mathrm{C} 1 \mathrm{~s}$ XPS spectra, which originate from the carbonate species $[42,43]$. The existence of these peaks indicates that the $\mathrm{Nb}_{2} \mathrm{O}_{5}$ nanoparticles are doped with $\mathrm{C}^{4+}$. Apart from the $\mathrm{C} 1 \mathrm{~s}$ spectra, the $\mathrm{O} 1 \mathrm{~s}$ spectra present a peak located at around $532 \mathrm{eV}$, which is ascribed to the carbonate species as well [44]. Table $\mathrm{S} 3$ shows that the pristine embedding $\mathrm{Nb}_{2} \mathrm{O}_{5} / \mathrm{C}$ nanohybrid presents the highest content of carbonate species, which inhibits the phase transition of the $\mathrm{Nb}_{2} \mathrm{O}_{5}$ nanoparticle. Thus, the phase transition is precluded at $900^{\circ} \mathrm{C}$ and the $\mathrm{Nb}_{2} \mathrm{O}_{5}$ nanoparticles remain as hexagonal phase. With carbon consumption through the $\mathrm{CO}_{2}$ activation process, the amount of the carbonate species decreases as indicated by the XPS spectra. The restriction effect of the carbon doping on the phase transition is weakened, where the phase transition from hexagonal to orthorhombic and monoclinic is observed.

Based on the comprehensive structure analyses of the $\mathrm{Nb}_{2} \mathrm{O}_{5} /$ carbon nanohybrids, the mechanism of the phase transition induced by the $\mathrm{CO}_{2}$ activation process is interpreted. The hexagonal phase of $\mathrm{Nb}_{2} \mathrm{O}_{5}$ is normally only stable in the temperature range from 500 to $600^{\circ} \mathrm{C}$, while phase transition tends to occur at elevated temperatures 

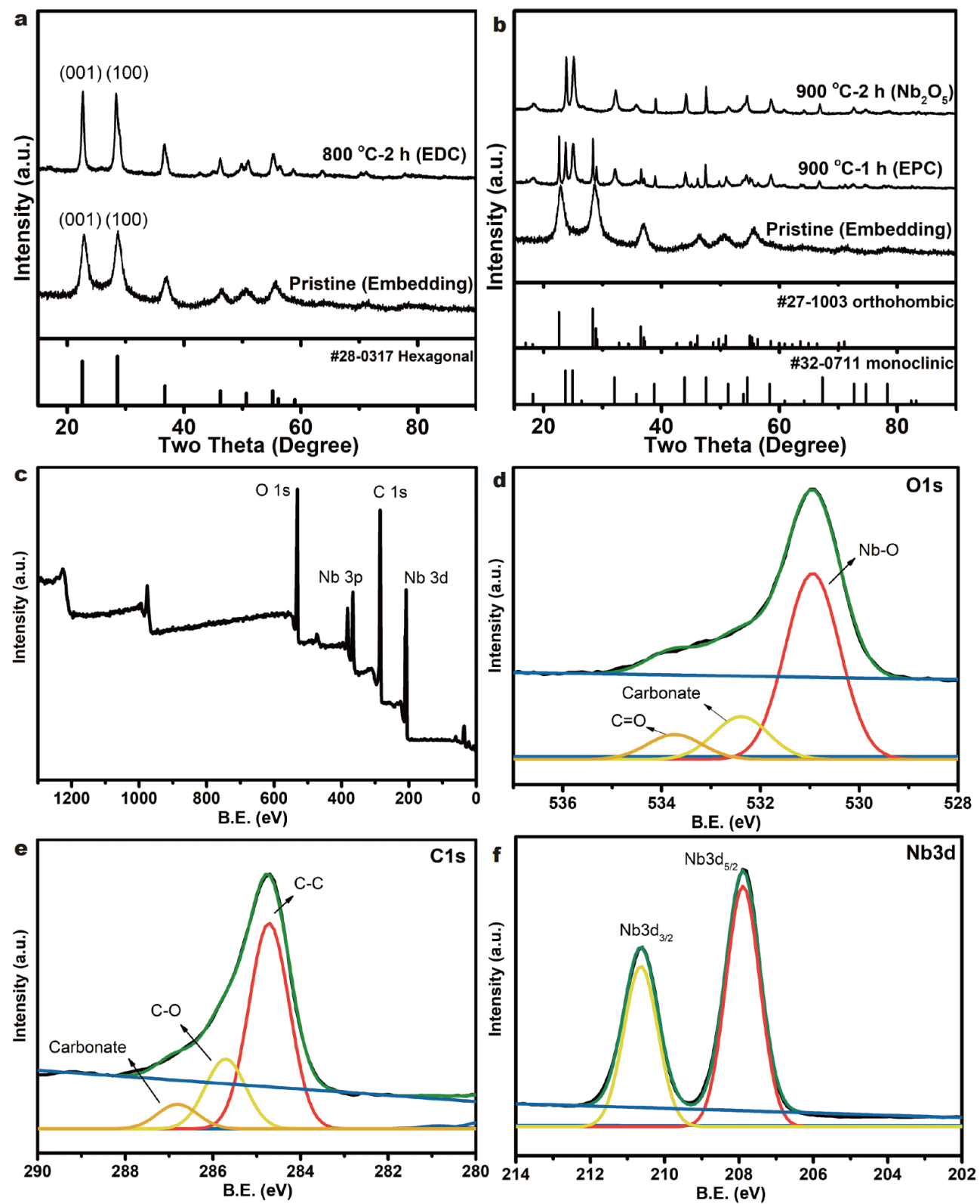

Figure 5 XRD patterns of the pristine carbon embedded $\mathrm{Nb}_{2} \mathrm{O}_{5} / \mathrm{C}$ and carbon emcoated (both EDC and EPC) $\mathrm{Nb}_{2} \mathrm{O}_{5} / \mathrm{C}$ nanohybrids (a, b). XPS survey (c) and high-resolution $\mathrm{O} 1 \mathrm{~s}(\mathrm{~d}), \mathrm{C} 1 \mathrm{~s}(\mathrm{e})$ and $\mathrm{Nb} 3 \mathrm{~d}$ (f) of the EPC structured $\mathrm{Nb}_{2} \mathrm{O}_{5} / \mathrm{C}$ nanohybrid.

Table 1 Relationship between heat-treatment temperature and crystallographic phase of $\mathrm{Nb}_{2} \mathrm{O}_{5}$ [45]

\begin{tabular}{cc}
\hline Temperature $\left({ }^{\circ} \mathrm{C}\right)$ & Crystallographic phase \\
\hline $500-600$ & Hexagonal \\
$600-800$ & Orthorhombic \\
900 & Monoclinic \\
\hline
\end{tabular}

$[45,46]$. However, the existence of dense carbon coating and carbon doping precludes the phase transition and the hexagonal phase is retained at $900^{\circ} \mathrm{C}$ in this study. When activated by $\mathrm{CO}_{2}$, the carbon species is etched, alleviating the mechanical stress and reducing the amount of the doped carbon simultaneously. As a result, the energy barrier for the phase transition is lowered, where the transition from hexagonal to orthorhombic and monoclinic phase occurs [47]. The phase transition from hexagonal phase to orthorhombic and further monoclinic phase is triggered with either extended time range or elevated temperature of the $\mathrm{CO}_{2}$ activation treatment. 
It is noted that, according to our previous studies, $\mathrm{Nb}_{2} \mathrm{O}_{5}$ would be reduced to $\mathrm{NbO}_{2}$ through Equations (1) and (2), which is generated from the residual amount of $\mathrm{CO}_{2}$ in the tube furnace [18]. While, in this study, under $\mathrm{CO}_{2}$ atmosphere, the abundant $\mathrm{CO}_{2}$ pushes the reaction of Equation (2) towards the left direction. Thus, $\mathrm{Nb}_{2} \mathrm{O}_{5}$ will not be reduced to $\mathrm{NbO}_{2}$.

$$
\begin{aligned}
& \mathrm{CO}_{2}+\mathrm{C} \rightarrow 2 \mathrm{CO}, \\
& \mathrm{CO}+\mathrm{Nb}_{2} \mathrm{O}_{5} \leftrightarrow 2 \mathrm{NbO}_{2}+\mathrm{CO}_{2} .
\end{aligned}
$$

The electrochemical performances of the $\mathrm{CO}_{2}$-activated $\mathrm{Nb}_{2} \mathrm{O}_{5} / \mathrm{C}$ nanohybrids were tested using CR-2032 coin type half-cells. Fig. 6a and Fig. S4 exhibit the CV curves of the activated samples at $0.2 \mathrm{mV} \mathrm{s}^{-1}$ with voltage range from 0.005 to $3.0 \mathrm{~V}$. No obvious redox peak is observed in the pristine carbon embedding $\mathrm{Nb}_{2} \mathrm{O}_{5} / \mathrm{C}$ nanohybrid due to poor crystallization of the $\mathrm{Nb}_{2} \mathrm{O}_{5}$ component. After
$\mathrm{CO}_{2}$ activation, the EDC structured $\mathrm{Nb}_{2} \mathrm{O}_{5} / \mathrm{C}$ nanohybrid shows redox couple of $\mathrm{Nb}^{4+} / \mathrm{Nb}^{5+}$ at $1.84 / 1.62 \mathrm{~V}$, referring to the delithiation/lithiation process of the orthorhombic $\mathrm{Nb}_{2} \mathrm{O}_{5}[48,49]$. The EPC structured $\mathrm{Nb}_{2} \mathrm{O}_{5} / \mathrm{C}$ nanohybrid and coral $\mathrm{Nb}_{2} \mathrm{O}_{5}$ present three redox pairs at $2.2 / 2.0 \mathrm{~V}$, $1.8 / 1.6 \mathrm{~V}$ and $1.25 / 1.17 \mathrm{~V}$, which are assigned to the lithium ion de-intercalation/intercalation process of the monoclinic $\mathrm{Nb}_{2} \mathrm{O}_{5}$. In addition, a small peak appears at $1.0-1.2 \mathrm{~V}$ in the first cycle, indicating the formation of solid electrolyte interphase (SEI) [50].

Charge and discharge profiles of the $\mathrm{CO}_{2}$-activated $\mathrm{Nb}_{2} \mathrm{O}_{5} / \mathrm{C}$ nanohybrids are displayed with a voltage range of $0.01-3.0 \mathrm{~V}$ at a current density of $40 \mathrm{~mA} \mathrm{~g}^{-1}$ (Fig. $6 \mathrm{~b}$ and Fig. S5). Apart from a small sloping plateau originating from the SEI formation process, no obvious plateau is observed in the first discharging cycle of the pristine carbon embedding $\mathrm{Nb}_{2} \mathrm{O}_{5} / \mathrm{C}$ nanohybrid
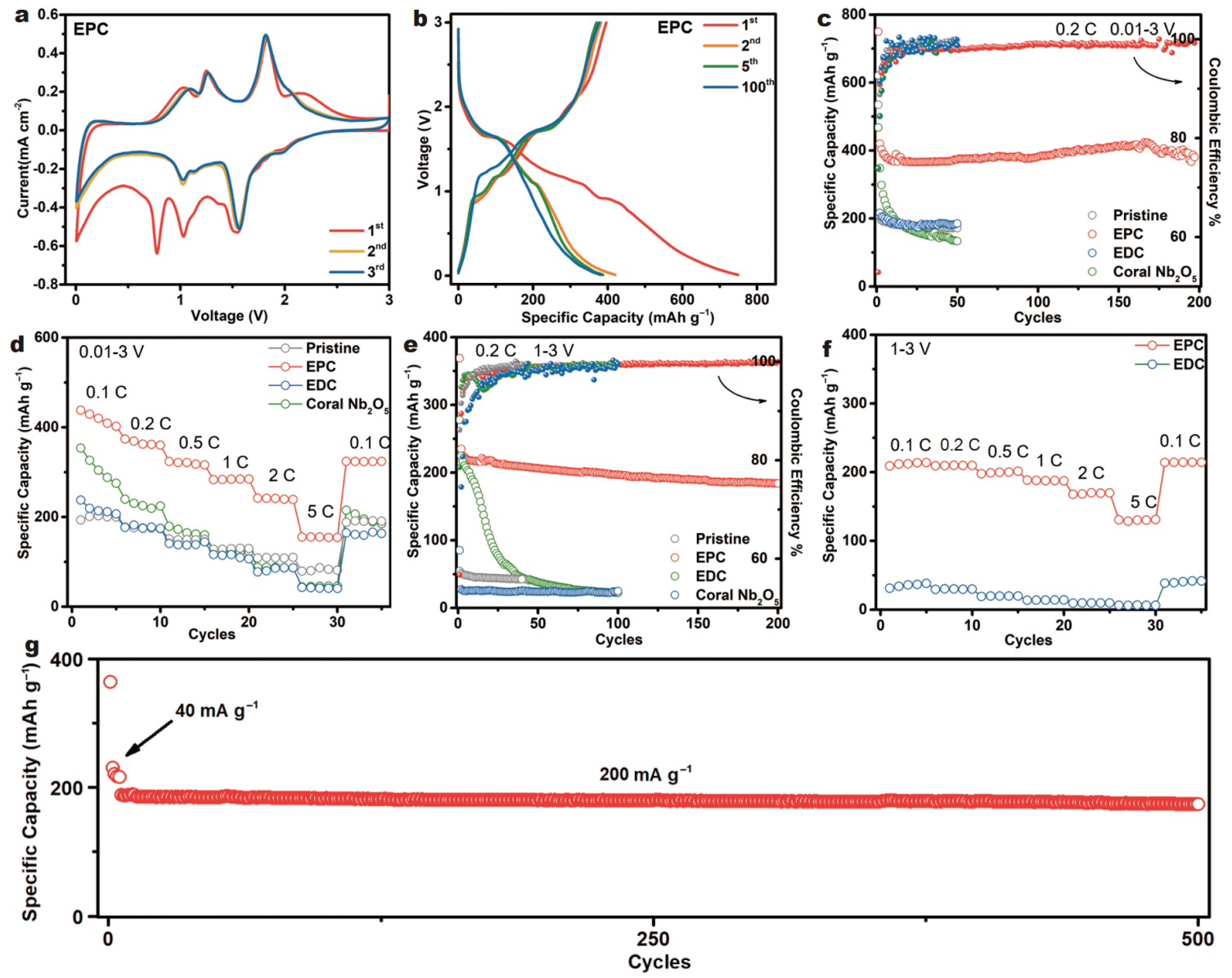

Figure 6 Electrochemical performance of the pristine carbon embedding $\mathrm{Nb}_{2} \mathrm{O}_{5} / \mathrm{C}$ and carbon emcoating $\mathrm{Nb}_{2} \mathrm{O}_{5} / \mathrm{C}\left(1 \mathrm{C}=200 \mathrm{~mA} \mathrm{~g}{ }^{-1}\right)$ : charge/ discharge profiles (a) and CV curves (b) of the EPC structured $\mathrm{Nb}_{2} \mathrm{O}_{5} / \mathrm{C}$; cycling (c) and rate (d) performances of the pristine carbon embedding $\mathrm{Nb}_{2} \mathrm{O}_{5} / \mathrm{C}$ and carbon emcoating $\mathrm{Nb}_{2} \mathrm{O}_{5} / \mathrm{C}$ with the voltage range of $0.01-3.0 \mathrm{~V}$; cycling (e), rate (f), and long cycling performance at $200 \mathrm{~mA} \mathrm{~g}^{-1}$ (g) with the cut-off voltage from 1.0 to $3.0 \mathrm{~V}$. 
(Fig. S5a). After the $\mathrm{CO}_{2}$ activation at $800^{\circ} \mathrm{C}$ with an enhanced crystallization, a small plateau appears at $1.5 \mathrm{~V}$ on discharge and $1.8 \mathrm{~V}$ on charge, consistent with the $\mathrm{CV}$ results (Fig. S5b). When the activation temperature increases to $900^{\circ} \mathrm{C}$, multiple plateaus between 1.0 and $2.0 \mathrm{~V}$ are shown in the EPC structured $\mathrm{Nb}_{2} \mathrm{O}_{5} / \mathrm{C}$ nanohybrid and coral $\mathrm{Nb}_{2} \mathrm{O}_{5}$ samples (Fig 6b, Fig. S5c). The main plateau at $1.6 \mathrm{~V}$ refers the sharp redox pair at $1.8 / 1.6 \mathrm{~V}$ in the CV profiles, which further confirms the charge/discharge behaviors of the monoclinic $\mathrm{Nb}_{2} \mathrm{O}_{5}$. The pristine carbon embedding $\mathrm{Nb}_{2} \mathrm{O}_{5} / \mathrm{C}$, EDC structured $\mathrm{Nb}_{2} \mathrm{O}_{5} / \mathrm{C}$, EPC structured $\mathrm{Nb}_{2} \mathrm{O}_{5} / \mathrm{C}$ and coral $\mathrm{Nb}_{2} \mathrm{O}_{5}$ deliver initial discharge/charge capacities of 535/192, 689/274, 750/396 and $468 / 345 \mathrm{~mA} \mathrm{~h} \mathrm{~g}^{-1}$, corresponding to initial coulombic efficiencies (ICE) of $35.9 \%, 39.8 \%, 52.8 \%$ and $73.7 \%$, respectively. The large irreversible capacity is ascribed to the intrinsic properties of resin-induced hard carbon and the formation of SEI on the surface of carbon matrix [50]. Thus, the ICE is improved after the $\mathrm{CO}_{2}$ activation process due to the decreased carbon content.

Cycling performance of the $\mathrm{Nb}_{2} \mathrm{O}_{5} / \mathrm{C}$ nanohybrids was measured at a current density of $40 \mathrm{~mA} \mathrm{~g}^{-1}$ (Fig. 6c). The EDC structured $\mathrm{Nb}_{2} \mathrm{O}_{5} / \mathrm{C}$ also presents improved cycling performance than the pristine sample, while the coral $\mathrm{Nb}_{2} \mathrm{O}_{5}$ shows poor reversibility in 50 cycles. The total removal of the carbon matrix by $\mathrm{CO}_{2}$ activation deteriorates the overall electron conductivity of the electrode and lack of carbon matrix makes it difficult to buffer the mechanical stress generated upon lithiation, which tends to accelerate capacity decay. The EPC structured $\mathrm{Nb}_{2} \mathrm{O}_{5} / \mathrm{C}$ shows the best performance, presenting a discharge capacity of $387 \mathrm{~mA} \mathrm{~h} \mathrm{~g}^{-1}$ after 200 cycles, which is nearly twice that of the pristine and other activated samples. It is worth noting that the specific capacity of the EPC structured $\mathrm{Nb}_{2} \mathrm{O}_{5} / \mathrm{C}$ is much higher than the theoretical value of $\mathrm{Nb}_{2} \mathrm{O}_{5}$ (ca. $200 \mathrm{~mA} \mathrm{~h} \mathrm{~g}^{-1}$ ), where the excessive lithium-ion storage is likely from the surface storage mechanism because of the increased surface area [51-53]. The $\mathrm{CO}_{2}$-activated $\mathrm{Nb}_{2} \mathrm{O}_{5}$ nanohybrids present improved rate performance at various current densities of 0.1 to $5 \mathrm{C}$, and the reversed current density of $0.1 \mathrm{C}$ (Fig. 6d). The EPC structured $\mathrm{Nb}_{2} \mathrm{O}_{5}$ delivers a specific capacity of $169 \mathrm{~mA} \mathrm{~h} \mathrm{~g}^{-1}$ at $5 \mathrm{C}$, corresponding with capacity retention of $37.6 \%$ with respect to the capacity at $0.1 \mathrm{C}$. In order to further investigate the cycling and rate performance, correlative measurements were conducted at the voltage window of 1.0-3.0 V. Fig. 6e shows that the EPC structured $\mathrm{Nb}_{2} \mathrm{O}_{5}$ remains a specific capacity of $184 \mathrm{~mA} \mathrm{~h} \mathrm{~g}^{-1}$ after 200 cycles, which retains $88 \%$ of the initial capacity. The specific capacity is nearly 5 times that of the pristine carbon-embedded $\mathrm{Nb}_{2} \mathrm{O}_{5}\left(42 \mathrm{~mA} \mathrm{~h} \mathrm{~g}^{-1}\right.$ after 40 cycles). The improved electrochemical performance at a reduced voltage window is due to enhanced crystallization of the $\mathrm{Nb}_{2} \mathrm{O}_{5}$ nanoparticles by $\mathrm{CO}_{2}$ activation. Regarding the rate performance, the EPC structured $\mathrm{Nb}_{2} \mathrm{O}_{5}$ presents capacity retentions of $99 \%, 93 \%$, $89 \%, 79 \%$ and $62 \%$ at current densities of $0.2,0.5,1,2$ and $5 \mathrm{C}$ (Fig. 6f). It is noted that coral $\mathrm{Nb}_{2} \mathrm{O}_{5}$ could not deliver comparable performances to the EPC structured $\mathrm{Nb}_{2} \mathrm{O}_{5}$ even coated with effective carbon matrix (Fig. S6), illustrating superior ion transportation in the EPC structure than conventional carbon coating. Fig. $6 \mathrm{~g}$ demonstrates the cycling stability of the EPC structured $\mathrm{Nb}_{2} \mathrm{O}_{5}$, delivering a capacity of $173 \mathrm{~mA} \mathrm{~h} \mathrm{~g}^{-1}$ after 500 cycles at $1 \mathrm{C}$. Both the cycling and rate performance of the $\mathrm{Nb}_{2} \mathrm{O}_{5} / \mathrm{C}$ nanohybrid is significantly improved by the emcoating technique, and to the best of our knowledge, the cycling performance of the EPC structured $\mathrm{Nb}_{2} \mathrm{O}_{5}$ is superior to the reported studies in both cut-off voltage ranges of $0.01-3 \mathrm{~V}$ and 1.0-3.0 V (Table 2).

To reveal the mechanism governing the high rate performance of the EPC structured $\mathrm{Nb}_{2} \mathrm{O}_{5}$, kinetics-related tests were carried out to determine the specific capacity contributions from the diffusion-controlled and capacitive processes [59]. Fig. 7a presents the $\mathrm{CV}$ measurements of the EPC structured $\mathrm{Nb}_{2} \mathrm{O}_{5}$ and pristine carbon embedding sample with scan rates from 0.2 to $1.2 \mathrm{mV} \mathrm{s}^{-1}$ and the strong redox peak pair at $1.5 \mathrm{~V}$ refers to the delithiation/lithiation of $\mathrm{Nb}_{2} \mathrm{O}_{5}$. With increasing scan rates, the redox peaks tend to be broad and shift to high voltage due to polarization. The cathodic peak is marked as Peak 1 , representing the lithium insertion process. According to Randles Sevcik equation, the peak current $\left(I_{p}, A\right)$ from

Table 2 Electrochemical performance of the reported $\mathrm{Nb}_{2} \mathrm{O}_{5}$-based negative electrodes

\begin{tabular}{ccccc}
\hline Electrode & $\begin{array}{c}\text { Potential } \\
\text { range (V) }\end{array}$ & $\begin{array}{c}\text { Gravimetric } \\
\text { capacity } \\
\left(\mathrm{mA} \mathrm{h} \mathrm{g}^{\text {t }}\right)\end{array}$ & $\begin{array}{c}\text { Current den- } \\
\text { sity }\left(\mathrm{mA} \mathrm{g}^{-1}\right)\end{array}$ & Ref. \\
\hline $\mathrm{NbO}_{2} / \mathrm{C}$ & $0.01-3.0$ & $225\left(500^{\text {th }}\right)$ & 200 & {$[18]$} \\
$\mathrm{NbO}_{\mathrm{x}} @ \mathrm{C}$ & $0.01-3.0$ & $298\left(100^{\text {th }}\right)$ & 100 & {$[54]$} \\
$\mathrm{Nb}_{2} \mathrm{O}_{5} / \mathrm{C}$ & $0.01-3.0$ & $385\left(100^{\text {th }}\right)$ & 100 & {$[55]$} \\
$\mathrm{Nb}_{2} \mathrm{O}_{5}$ capsule & $0-3$ & $421\left(100^{\text {th }}\right)$ & 100 & {$[56]$} \\
$\mathrm{Vein}-{\mathrm{like} \mathrm{Nb}_{2} \mathrm{O}_{5}}$ & $1.0-3.0$ & $201\left(50^{\text {th }}\right)$ & 200 & {$[49]$} \\
$\mathrm{Nb}_{2} \mathrm{O}_{5} / \mathrm{CNTS}^{\mathrm{th}}$ & $1.0-3.0$ & $168\left(500^{\text {th }}\right)$ & 100 & {$[56]$} \\
$\mathrm{Nb}_{2} \mathrm{O}_{5} / \mathrm{NbO}_{2}$ & $1.0-3.0$ & $123\left(900^{\text {th }}\right)$ & 200 & {$[57]$} \\
$\mathrm{Nb}_{2} \mathrm{O}_{5}$ & $1.2-3.0$ & $140\left(200^{\text {th }}\right)$ & 100 & {$[58]$} \\
$\mathrm{Nb}_{2} \mathrm{O}_{5} / \mathrm{C}$ & $0.01-3.0$ & $387\left(200^{\text {th }}\right)$ & 40 & This work \\
\hline
\end{tabular}



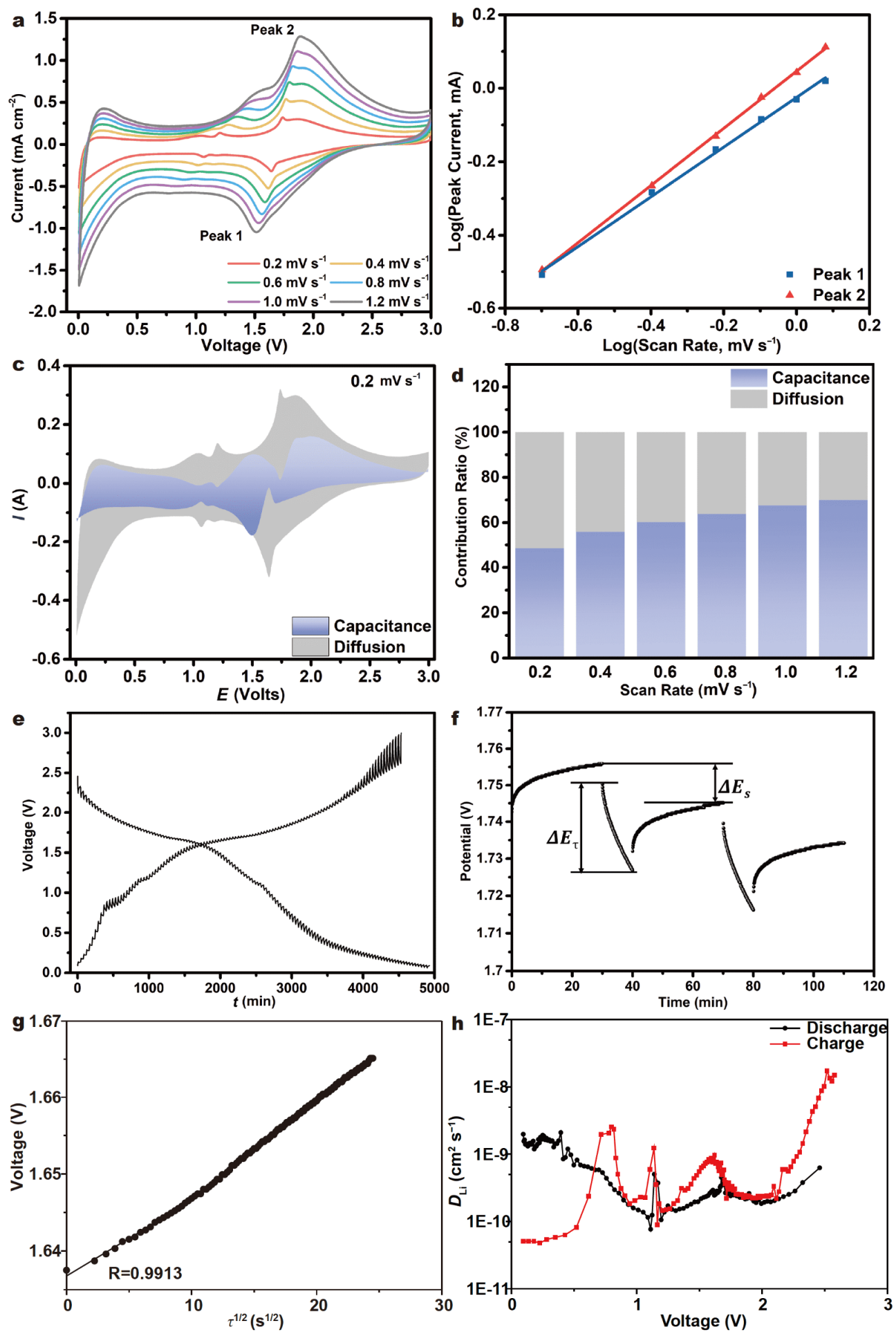

Figure 7 Kinetics analyses of the lithium ion storage mechanism of the EPC structured $\mathrm{Nb}_{2} \mathrm{O}_{5} / \mathrm{C}$. Details: CV profiles at various scan rates (a); relationship between the peak current and scan rate in logarithmic format (b); capacitive contribution at a scan rate of $0.2 \mathrm{mV} \mathrm{s}^{-1}$ (c); contribution ratio of the capacitive and diffusion-controlled capacities at various scan rates (d). GITT analyses of the EPC structured $\mathrm{Nb}_{2} \mathrm{O}_{5}$. Details: GITT profiles of the discharge/charge process (e); single step of the GITT curves (f); linear fit of $E$ versus $\tau^{1 / 2}$ for a typical titration (g); apparent lithium diffusion coefficient $\left(D_{\mathrm{Li}}\right)$ of the EPC structured $\mathrm{Nb}_{2} \mathrm{O}_{5} / \mathrm{C}$ calculated from the GITT profiles (h). Additionally, the EIS results (Fig. S8) confirm the improved diffusion behavior from the unique carbon structure as well. 
the CV scans can be applied to estimate the lithium diffusion coefficient, $D_{\mathrm{Li}}{ }^{+}\left(\mathrm{cm}^{2} \mathrm{~s}^{-1}\right)$ [60]:

$I_{\mathrm{p}}=2.69 \times 10^{5} n^{3 / 2} A D^{1 / 2} v^{1 / 2} C$.

According to Randles Sevcik equation, the lithium diffusion coefficients of the EPC structured $\mathrm{Nb}_{2} \mathrm{O}_{5}$ and pristine carbon embedding $\mathrm{Nb}_{2} \mathrm{O}_{5}$ are estimated as $4.3 \times 10^{-11}$ and $7.3 \times 10^{-13} \mathrm{~cm}^{2} \mathrm{~s}^{-1}$, respectively (Fig. S7).

In addition, the contribution of the capacitance process can be analyzed by the equation below:

$i=a v^{b}$,

where $i$ stands for the peak current, $a$ and $b$ are adjustable constants [61,62]. The $a$ and $b$ values are empirical parameters, which can be calculated by fitting the $\log (v)$ $\log (i)$ plot (Fig. $7 \mathrm{~b})$. Note that the $b$ value indicates the contribution of diffusion-controlled process and surface capacitance process. When the $b$ value is close to 1 , it represents a surface-controlled intercalation process. While the $b$ value is close to 0.5 , a diffusion-controlled process is dominating [61]. From the slope of $\log (v)-\log$ (i), the $b$ values of cathodic (peak 1) and anodic (peak 2) are 0.68 and 0.78 , respectively, which illustrates a surfacecontrolled process of the EPC structured $\mathrm{Nb}_{2} \mathrm{O}_{5} / \mathrm{C}$. In addition, the contribution of the diffusion process and capacitance process can be extracted from the following equation:

$i=k_{1} v+k_{2} v^{1 / 2}$,

where $k_{1} v$ stands for the contribution of the surface capacitance and $k_{2} v^{1 / 2}$ stands for the contribution of the diffusion-controlled process. Fig. 7c, d depict that the proportion of capacitance contribution is $48.6 \%$ at the scan rate of $0.2 \mathrm{mV} \mathrm{s}^{-1}$. With increasing scan rates to $1.2 \mathrm{mV} \mathrm{s}^{-1}$, the proportion rises to $70.0 \%$. Thus, the majority of the lithium storage of the EPC structured $\mathrm{Nb}_{2} \mathrm{O}_{5}$ originates from the capacitive behavior, which conduces to the excellent high rate performance.

GITT experiment was applied to investigate the lithium ion diffusion coefficient of the EPC structured $\mathrm{Nb}_{2} \mathrm{O}_{5}$. The cell was cycled at $0.1 \mathrm{C}$ to reach stabilized cycling performances before mesurement. Fig. 7e shows the data for the GITT analysis during the discharge/charge process. The apparent $D_{\mathrm{Li}}{ }^{+}$can be estimated based on the equation derived from Fick's second law [63-65]:

$D_{\mathrm{Li}}=\frac{4}{\pi}\left(\frac{m_{\mathrm{B}} V_{\mathrm{m}}}{M_{\mathrm{B}} S}\right)^{2}\left(\frac{\Delta E_{\mathrm{S}}}{\tau\left(\mathrm{d} E_{\tau} / \mathrm{d} \sqrt{\tau}\right)}\right)^{2}, \tau \ll \frac{L^{2}}{D_{\mathrm{Li}}}$,

where $m_{\mathrm{B}}, M_{\mathrm{B}}$ and $V_{\mathrm{m}}$ are the real mass, molar mass and molar volume of the active material, respectively. $S$ is the area of the electrode and $\tau$ is the current pulse time. $\Delta E_{\tau}$ is the potential change caused by pulse current in a singlestep GITT experiment and $\Delta E_{S}$ is transient potential change after eliminating the IR drop, which can be extracted from Fig. 7f. From Fig. 7g, it can be extracted that $E$ and $\tau^{1 / 2}$ present linear relationship during single titration. Thus, Equation (6) can be simplified as follow [6365]:

$D_{\mathrm{Li}}=\frac{4}{\pi \tau}\left(\frac{m_{\mathrm{B}} V_{\mathrm{m}}}{M_{\mathrm{B}} S}\right)^{2}\left(\frac{\Delta E_{\mathrm{S}}}{\Delta E_{\tau}}\right)^{2}, \tau \ll \frac{L^{2}}{D_{\mathrm{Li}}}$.

$D_{\mathrm{Li}+}$ of the EPC structured $\mathrm{Nb}_{2} \mathrm{O}_{5} / \mathrm{C}$ during de-lithiation/lithiation process is calculated ranging from $10^{-10}$ to $10^{-18} \mathrm{~cm}^{2} \mathrm{~s}^{-1}$ (Fig. 7h). The lithium diffusion coefficient calculated from GITT matches well with the results from the $\mathrm{CV}$ analysis, which further confirms the rapid lithium ion diffusion behavior of the EPC structured $\mathrm{Nb}_{2} \mathrm{O}_{5} / \mathrm{C}$ nanohybrid.

The improved electrochemical performance of the EPC structured $\mathrm{Nb}_{2} \mathrm{O}_{5}$ is attributed to the unique structure from the effect of $\mathrm{CO}_{2}$ activation process. The crystal phase of the $\mathrm{Nb}_{2} \mathrm{O}_{5}$ component is modified and crystallization is also enhanced. With increasing crystallinity, lithiation plateau is prolonged. Besides, the bulk structure is tuned from embedding to interconnected and mesoporous carbon emcoating structure after $\mathrm{CO}_{2}$ activation, and the contact area between electrolyte and electrode is increased and the diffusion path is largely shortened, which facilitate the electron and ion transport. Compared with conventional coating structure, the interconnected carbon matrix provides more carbon composition on the surface of the $\mathrm{Nb}_{2} \mathrm{O}_{5}$ nanoparticles. In addition, re-constructed surface and increase of surface area enhance lithium-ion storage capability due to the additional surface lithium storage process for the $\mathrm{CO}_{2}$-activated $\mathrm{Nb}_{2} \mathrm{O}_{5} / \mathrm{C}$ nanohybrids.

The intercalation negative electrode was implicated with gassing problems, which hampers the practical application $[23,66]$. The gassing behavior of the EPC structured $\mathrm{Nb}_{2} \mathrm{O}_{5}$ electrode was explored with differential electrochemical mass spectrometry (DEMS) (Fig. 8a). Gas species with molecular weights of $44,30,28$, and 2 were monitored to characterize $\mathrm{CO}_{2}, \mathrm{C}_{2} \mathrm{H}_{6}, \mathrm{C}_{2} \mathrm{H}_{4}$ and $\mathrm{H}_{2}$, respectively. Commercial lithium titanate (LTO) was applied as the control sample (Fig. 8b). The gas evolution profiles for the first galvanostatic discharge/charge cycles at $0.1 \mathrm{C}$ are presented. During the discharge process, different from LTO, gas evolution of $\mathrm{C}_{2} \mathrm{H}_{4}$ and $\mathrm{C}_{2} \mathrm{H}_{6}$ is observed, which could be attributed to the reduction of EC and DMC $[23,67,68]$. The origination of $\mathrm{H}_{2}$ during discharge is assigned to the reduction of trace water from 

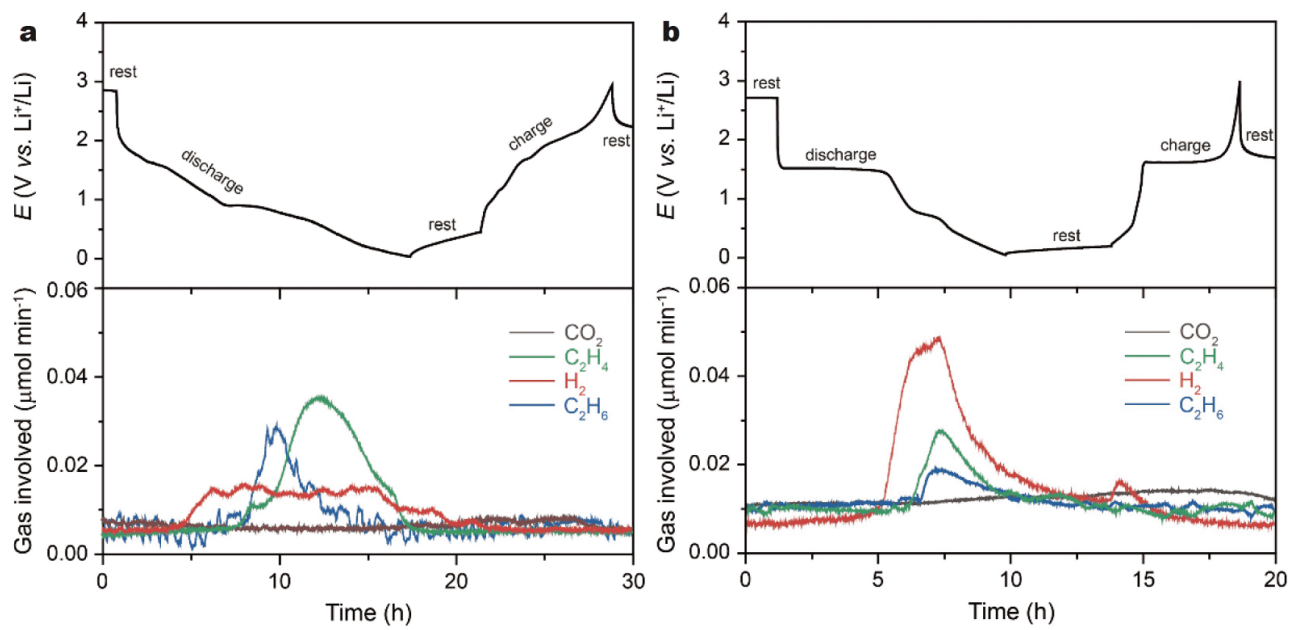

Figure 8 DEMS patterns with initial discharge/charge cycle of the EPC structured $\mathrm{Nb}_{2} \mathrm{O}_{5} / \mathrm{C}$ (a) and commercial LTO electrode (b).

the electrode [69]. Nevertheless, as the feature gas of the LTO electrode from the reduction of $\mathrm{Ti}^{4+}$ to $\mathrm{Ti}^{3+}, \mathrm{CO}_{2}$ is only observed in the LTO electrode [70]. After integration, the specific gas amounts of the EPC structured $\mathrm{Nb}_{2} \mathrm{O}_{5} / \mathrm{C}$ nanohybrid and LTO are calculated as 2.47 and $3.04 \mu \mathrm{mol}$, implying that the EPC structured $\mathrm{Nb}_{2} \mathrm{O}_{5} / \mathrm{C}$ nanohybrid exhibits a reduced gas evolution behavior than the commercial LTO electrode.

\section{CONCLUSIONS}

In summary, $\mathrm{Nb}_{2} \mathrm{O}_{5} / \mathrm{C}$ nanohybrid with the carbon-emcoating architecture was constructed through $\mathrm{CO}_{2}$ activation treatment of the $\mathrm{Nb}_{2} \mathrm{O}_{5} / \mathrm{C}$ sample with the $\mathrm{Nb}_{2} \mathrm{O}_{5}$ nanoparticles embedded in the carbon matrix. Triple structure engineering of the carbon-emcoated $\mathrm{Nb}_{2} \mathrm{O}_{5} / \mathrm{C}$ nanohybrid is achieved by the $\mathrm{CO}_{2}$ activation process, where the content and microstructure of the carbon matrix, and crystallographic phase of the $\mathrm{Nb}_{2} \mathrm{O}_{5}$ are well tuned. Compared with the typical carbon-coating and carbon-embedding structure, dominant interior surface of the $\mathrm{Nb}_{2} \mathrm{O}_{5}$ nanoparticulate agglomerate is covered by the continuous porous carbon within the carbon-emcoated $\mathrm{Nb}_{2} \mathrm{O}_{5} / \mathrm{C}$ nanohybrid. Superior electrochemical performance is exhibited by the EPC structured $\mathrm{Nb}_{2} \mathrm{O}_{5} / \mathrm{C}$ nanohybrid with a discharging capacity of $387 \mathrm{~mA} \mathrm{~h} \mathrm{~g}^{-1}$ over 200 cycles. With the narrowed voltage window of $1.0-3.0 \mathrm{~V}$, a capacity of $173 \mathrm{~mA} \mathrm{~h} \mathrm{~g}^{-1}$ is maintained after 500 cycles. The $D_{\mathrm{Li}}{ }^{+}$of the EPC structured $\mathrm{Nb}_{2} \mathrm{O}_{5} / \mathrm{C}$ nanohybrid shows two order of magnitude higher than that of non-activated samples. The DEMS profile indicates that the EPC structured $\mathrm{Nb}_{2} \mathrm{O}_{5} / \mathrm{C}$ nanohybrid exhibits reduced gassing behavior compared with the commercial lithium titanate counterpart. The paper provides a facile method and fundamental understanding about construction of the carbon-emcoating architecture towards high-performance energy storage materials.

Received 2 July 2020; accepted 30 September 2020; published online 24 December 2020

1 Ohzuku T, Ueda A, Yamamoto N. Zero-strain insertion material of $\mathrm{Li}\left[\mathrm{Li}_{1 / 3} \mathrm{Ti}_{5 / 3}\right] \mathrm{O}_{4}$ for rechargeable lithium cells. J Electrochem Soc, 1995, 142: 1431-1435

2 Poizot P, Laruelle S, Grugeon S, et al. Nano-sized transition-metal oxides as negative-electrode materials for lithium-ion batteries. Nature, 2000, 407: 496-499

3 Hu YS, Kienle L, Guo YG, et al. High lithium electroactivity of nanometer-sized rutile $\mathrm{TiO}_{2}$. Adv Mater, 2006, 18: 1421-1426

4 Zhao Y, Wang LP, Sougrati MT, et al. A review on design strategies for carbon based metal oxides and sulfides nanocomposites for high performance $\mathrm{Li}$ and $\mathrm{Na}$ ion battery anodes. Adv Energy Mater, 2017, 7: 1601424

5 Kim KT, Yu CY, Yoon CS, et al. Carbon-coated $\mathrm{Li}_{4} \mathrm{Ti}_{5} \mathrm{O}_{12}$ nanowires showing high rate capability as an anode material for rechargeable sodium batteries. Nano Energy, 2015, 12: 725-734

6 Li N, Zhou G, Li F, et al. A self-standing and flexible electrode of $\mathrm{Li}_{4} \mathrm{Ti}_{5} \mathrm{O}_{12}$ nanosheets with a $\mathrm{N}$-doped carbon coating for high rate lithium ion batteries. Adv Funct Mater, 2013, 23: 5429-5435

7 Zhu GN, Liu HJ, Zhuang JH, et al. Carbon-coated nano-sized $\mathrm{Li}_{4} \mathrm{Ti}_{5} \mathrm{O}_{12}$ nanoporous micro-sphere as anode material for high-rate lithium-ion batteries. Energy Environ Sci, 2011, 4: 4016-4022

8 Ko YN, Park SB, Jung KY, et al. One-pot facile synthesis of antcave-structured metal oxide-carbon microballs by continuous process for use as anode materials in Li-ion batteries. Nano Lett, 2013, 13: 5462-5466

9 Li W, Wang F, Feng S, et al. Sol-gel design strategy for ultradispersed $\mathrm{TiO}_{2}$ nanoparticles on graphene for high-performance lithium ion batteries. J Am Chem Soc, 2013, 135: 18300-18303

10 Liu Y, Zhang N, Jiao L, et al. Ultrasmall Sn nanoparticles em- 
bedded in carbon as high-performance anode for sodium-ion batteries. Adv Funct Mater, 2015, 25: 214-220

11 Chen Z, Dahn JR. Reducing carbon in $\mathrm{LiFePO}_{4} / \mathrm{C}$ composite electrodes to maximize specific energy, volumetric energy, and tap density. J Electrochem Soc, 2002, 149: A1184

12 Ko YN, Kang YC. $\mathrm{Co}_{9} \mathrm{~S}_{8}$-carbon composite as anode materials with improved Na-storage performance. Carbon, 2015, 94: 85-90

$13 \mathrm{Lu} \mathrm{Y}$, Zhang $\mathrm{N}$, Zhao Q, et al. Micro-nanostructured $\mathrm{CuO} / \mathrm{C}$ spheres as high-performance anode materials for $\mathrm{Na}$-ion batteries. Nanoscale, 2015, 7: 2770-2776

14 Zhang $\mathrm{N}$, Han $\mathrm{X}$, Liu $\mathrm{Y}$, et al. 3D porous $\gamma-\mathrm{Fe}_{2} \mathrm{O}_{3} @ \mathrm{C}$ nanocomposite as high-performance anode material of $\mathrm{Na}$-ion batteries. Adv Energy Mater, 2015, 5: 1401123

15 Xiao Y, Wang X, Xia Y, et al. Green facile scalable synthesis of titania/carbon nanocomposites: new use of old dental resins. ACS Appl Mater Interfaces, 2014, 6: 18461-18468

16 Wang $\mathrm{X}$, Meng JQ, Wang $\mathrm{M}$, et al. Facile scalable synthesis of $\mathrm{TiO}_{2}$ /carbon nanohybrids with ultrasmall $\mathrm{TiO}_{2}$ nanoparticles homogeneously embedded in carbon matrix. ACS Appl Mater Interfaces, 2015, 7: 24247-24255

17 Zheng L, Wang X, Xia Y, et al. Scalable in situ synthesis of $\mathrm{Li}_{4} \mathrm{Ti}_{5} \mathrm{O}_{12} /$ carbon nanohybrid with supersmall $\mathrm{Li}_{4} \mathrm{Ti}_{5} \mathrm{O}_{12}$ nanoparticles homogeneously embedded in carbon matrix. ACS Appl Mater Interfaces, 2018, 10: 2591-2602

18 Ji Q, Gao X, Zhang Q, et al. Dental resin monomer enables unique $\mathrm{NbO}_{2} /$ carbon lithium-ion battery negative electrode with exceptional performance. Adv Funct Mater, 2019, 29: 1904961

19 Wang X, Ma L, Ji Q, et al. MnO/metal/carbon nanohybrid lithiumion battery anode with enhanced electrochemical performance: universal facile scalable synthesis and fundamental understanding. Adv Mater Interfaces, 2019, 6: 1900335

20 Yang Z, Shen J, Archer LA. An in situ method of creating metal oxide-carbon composites and their application as anode materials for lithium-ion batteries. J Mater Chem, 2011, 21: 11092

21 Chen $\mathrm{Y}, \mathrm{Ma} \mathrm{X}$, Cui X, et al. In situ synthesis of carbon incorporated $\mathrm{TiO}_{2}$ with long-term performance as anode for lithiumion batteries. J Power Sources, 2016, 302: 233-239

22 Cao S, Feng X, Song Y, et al. In situ carbonized cellulose-based hybrid film as flexible paper anode for lithium-ion batteries. ACS Appl Mater Interfaces, 2016, 8: 1073-1079

$23 \mathrm{He} \mathrm{M}$, Castel E, Laumann A, et al. In situ gas analysis of $\mathrm{Li}_{4} \mathrm{Ti}_{5} \mathrm{O}_{12}$ based electrodes at elevated temperatures. J Electrochem Soc, 2015, 162: A870-A876

24 Gao X, Chen Y, Johnson L, et al. Promoting solution phase discharge in $\mathrm{Li}-\mathrm{O}_{2}$ batteries containing weakly solvating electrolyte solutions. Nat Mater, 2016, 15: 882-888

25 Chen Y, Freunberger SA, Peng Z, et al. $\mathrm{Li}-\mathrm{O}_{2}$ battery with a dimethylformamide electrolyte. J Am Chem Soc, 2012, 134: 79527957

26 Ryu SK, Jin H, Gondy D, et al. Activation of carbon fibres by steam and carbon dioxide. Carbon, 1993, 31: 841-842

27 Rodríguez-Reinoso F, Molina-Sabio M, González MT. The use of steam and $\mathrm{CO}_{2}$ as activating agents in the preparation of activated carbons. Carbon, 1995, 33: 15-23

28 Xia $\mathrm{K}, \mathrm{Gao} \mathrm{Q}, \mathrm{Wu} \mathrm{C}$, et al. Activation, characterization and hydrogen storage properties of the mesoporous carbon CMK-3. Carbon, 2007, 45: 1989-1996

29 Xia K, Gao Q, Jiang J, et al. Hierarchical porous carbons with controlled micropores and mesopores for supercapacitor electrode materials. Carbon, 2008, 46: 1718-1726
30 Xia K, Gao Q, Song S, et al. $\mathrm{CO}_{2}$ activation of ordered porous carbon CMK-1 for hydrogen storage. Int J Hydrogen Energy, 2008, 33: 116-123

31 Sevilla M, Mokaya R. Energy storage applications of activated carbons: supercapacitors and hydrogen storage. Energy Environ Sci, 2014, 7: 1250-1280

32 Zhang Y, Park SJ. Incorporation of $\mathrm{RuO}_{2}$ into charcoal-derived carbon with controllable microporosity by $\mathrm{CO}_{2}$ activation for highperformance supercapacitor. Carbon, 2017, 122: 287-297

33 Roh JS. Structural study of the activated carbon fiber using laser Raman spectroscopy. Carbon Lett, 2008, 9: 127-130

34 Balachandran U, Eror NG. Raman spectrum of the high temperature form of $\mathrm{Nb}_{2} \mathrm{O}_{5}$. J Mater Sci Lett, 1982, 1: 374-376

35 Schrader B, Bergmann G. Die Intensität des Ramanspektrums polykristalliner Substanzen. Z Anal Chem, 1967, 225: 230-247

36 Zhu S, Li J, Ma L, et al. Three-dimensional network of N-doped carbon ultrathin nanosheets with closely packed mesopores: controllable synthesis and application in electrochemical energy storage. ACS Appl Mater Interfaces, 2016, 8: 11720-11728

37 Hubbard CR, Snyder RL. RIR-measurement and use in quantitative XRD. Powder Diffr, 2013, 3: 74-77

38 Li Y, Zhang S, Yu Q, et al. The effects of activated carbon supports on the structure and properties of $\mathrm{TiO}_{2}$ nanoparticles prepared by a sol-gel method. Appl Surf Sci, 2007, 253: 9254-9258

39 Li Q, Liu B, Li Y, et al. Ethylene glycol-mediated synthesis of nanoporous anatase $\mathrm{TiO}_{2}$ rods and rutile $\mathrm{TiO}_{2}$ self-assembly chrysanthemums. J Alloys Compd, 2009, 471: 477-480

40 Bailón-García E, Elmouwahidi A, Álvarez MA, et al. New carbon xerogel- $\mathrm{TiO}_{2}$ composites with high performance as visible-light photocatalysts for dye mineralization. Appl Catal B-Environ, 2017, 201: $29-40$

$41 \mathrm{Du} \mathrm{X}, \mathrm{Wu} \mathrm{Y}$, Kou Y, et al. Amorphous carbon inhibited $\mathrm{TiO}_{2}$ phase transition in aqueous solution and its application in photocatalytic degradation of organic dye. J Alloys Compd, 2019, 810: 151917

42 Xiao Q, Zhang J, Xiao C, et al. Solar photocatalytic degradation of methylene blue in carbon-doped $\mathrm{TiO}_{2}$ nanoparticles suspension. Sol Energy, 2008, 82: 706-713

43 Ohno T, Tsubota T, Toyofuku M, et al. Photocatalytic activity of a $\mathrm{TiO}_{2}$ photocatalyst doped with $\mathrm{C}^{4+}$ and $\mathrm{S}^{4+}$ ions having a rutile phase under visible light. Catal Lett, 2004, 98: 255-258

44 Yabuuchi N, Yoshii K, Myung ST, et al. Detailed studies of a highcapacity electrode material for rechargeable batteries, $\mathrm{Li}_{2} \mathrm{MnO}_{3}$ $-\mathrm{LiCo}_{1 / 3} \mathrm{Ni}_{1 / 3} \mathrm{Mn}_{1 / 3} \mathrm{O}_{2}$. J Am Chem Soc, 2011, 133: 4404-4419

45 Schäfer H, Gruehn R, Schulte F. Die Modifikationen des Niobpentoxids. Angew Chem, 1966, 78: 28-41

46 Pilarek B, Pelczarska AJ, Szczygieł I. Characterization of niobium (V) oxide received from different sources. J Therm Anal Calorim, 2017, 130: 77-83

47 Valencia-Balvín C, Pérez-Walton S, Dalpian GM, et al. Firstprinciples equation of state and phase stability of niobium pentoxide. Comput Mater Sci, 2014, 81: 133-140

48 Viet AL, Reddy MV, Jose $\mathrm{R}$, et al. Nanostructured $\mathrm{Nb}_{2} \mathrm{O}_{5}$ polymorphs by electrospinning for rechargeable lithium batteries. J Phys Chem C, 2010, 114: 664-671

49 Rahman MM, Rani RA, Sadek AZ, et al. A vein-like nanoporous network of $\mathrm{Nb}_{2} \mathrm{O}_{5}$ with a higher lithium intercalation discharge cut-off voltage. J Mater Chem A, 2013, 1: 11019-11025

50 Flandrois S, Simon B. Carbon materials for lithium-ion rechargeable batteries. Carbon, 1999, 37: 165-180 
51 Duan Y, Zhang B, Zheng J, et al. Excess Li-ion storage on reconstructed surfaces of nanocrystals to boost battery performance. Nano Lett, 2017, 17: 6018-6026

52 Shin JY, Samuelis D, Maier J. Sustained lithium-storage performance of hierarchical, nanoporous anatase $\mathrm{TiO}_{2}$ at high rates: emphasis on interfacial storage phenomena. Adv Funct Mater, 2011, 21: 3464-3472

53 Kumagai N, Koishikawa Y, Komaba S, et al. Thermodynamics and kinetics of lithium intercalation into $\mathrm{Nb}_{2} \mathrm{O}_{5}$ electrodes for a $2 \mathrm{~V}$ rechargeable lithium battery. J Electrochem Soc, 1999, 146: 32033210

54 Cai Y, Li X, Wang L, et al. Oleylamine-assisted hydrothermal synthesis of ultrasmall $\mathrm{NbO}_{x}$ nanoparticles and their in situ conversion to $\mathrm{NbO}_{x} @ \mathrm{C}$ with highly reversible lithium storage. J Mater Chem A, 2015, 3: 1396-1399

55 Lin J, Yuan Y, Su Q, et al. Facile synthesis of $\mathrm{Nb}_{2} \mathrm{O}_{5} /$ carbon nanocomposites as advanced anode materials for lithium-ion batteries. Electrochim Acta, 2018, 292: 63-71

$56 \mathrm{Wu}$ W, Huang J, Li J, et al. Inducing [001]-orientation in $\mathrm{Nb}_{2} \mathrm{O}_{5}$ capsule-nanostructure for promoted $\mathrm{Li}^{+}$diffusion process. Electrochim Acta, 2019, 298: 449-458

57 Park $\mathrm{H}$, Lee D, Song T. High capacity monoclinic $\mathrm{Nb}_{2} \mathrm{O}_{5}$ and semiconducting $\mathrm{NbO}_{2}$ composite as high-power anode material for Li-Ion batteries. J Power Sources, 2019, 414: 377-382

58 Cao D, Yao Z, Liu J, et al. $\mathrm{H}-\mathrm{Nb}_{2} \mathrm{O}_{5}$ wired by tetragonal tungsten bronze related domains as high-rate anode for Li-ion batteries. Energy Storage Mater, 2018, 11: 152-160

59 Chao D, Zhu C, Yang P, et al. Array of nanosheets render ultrafast and high-capacity Na-ion storage by tunable pseudocapacitance. Nat Commun, 2016, 7: 12122

60 Dahn JR, Jiang J, Moshurchak LM, et al. High-rate overcharge protection of $\mathrm{LiFePO}_{4}$-based Li-ion cells using the redox shuttle additive 2,5-ditertbutyl-1,4-dimethoxybenzene. J Electrochem Soc, 2005, 152: A1283

61 Lindström $\mathrm{H}$, Södergren $\mathrm{S}$, Solbrand $\mathrm{A}$, et al. $\mathrm{Li}^{+}$ion insertion in $\mathrm{TiO}_{2}$ (anatase). 2. Voltammetry on nanoporous films. J Phys Chem B, 1997, 101: 7717-7722

62 Augustyn V, Simon P, Dunn B. Pseudocapacitive oxide materials for high-rate electrochemical energy storage. Energy Environ Sci, 2014, 7: 1597-1614

63 Weppner W, Huggins RA. Determination of the kinetic parameters of mixed-conducting electrodes and application to the system $\mathrm{Li}_{3} \mathrm{Sb}$. J Electrochem Soc, 1977, 124: 1569-1578

64 Inada $\mathrm{R}$, Kumasaka $\mathrm{R}$, Inabe $\mathrm{S}$, et al. $\mathrm{Li}^{+}$insertion/extraction properties for $\mathrm{TiNb}_{2} \mathrm{O}_{7}$ single particle characterized by a particlecurrent collector integrated microelectrode. J Electrochem Soc, 2019, 166: A5157-A5162

65 Rui XH, Ding N, Liu J, et al. Analysis of the chemical diffusion coefficient of lithium ions in $\mathrm{Li}_{3} \mathrm{~V}_{2}\left(\mathrm{PO}_{4}\right)_{3}$ cathode material. Electrochim Acta, 2010, 55: 2384-2390

66 Lanz M, Novák P. DEMS study of gas evolution at thick graphite electrodes for lithium-ion batteries: the effect of $\gamma$-butyrolactone. J Power Sources, 2001, 102: 277-282

67 Onuki M, Kinoshita S, Sakata Y, et al. Identification of the source of evolved gas in Li-ion batteries using ${ }^{13} \mathrm{C}$-labeled solvents. J Electrochem Soc, 2008, 155: A794

68 He YB, Li B, Liu M, et al. Gassing in $\mathrm{Li}_{4} \mathrm{Ti}_{5} \mathrm{O}_{12}$-based batteries and its remedy. Sci Rep, 2012, 2: 913

69 Bernhard R, Meini S, Gasteiger HA. On-line electrochemical mass spectrometry investigations on the gassing behavior of $\mathrm{Li}_{4} \mathrm{Ti}_{5} \mathrm{O}_{12}$ electrodes and its origins. J Electrochem Soc, 2014, 161: A497A505

70 Fell CR, Sun L, Hallac PB, et al. Investigation of the gas generation in lithium titanate anode based lithium ion batteries. J Electrochem Soc, 2015, 162: A1916-A1920

Acknowledgements The authors thank Prof. Dr. Zhicheng Zhong and Dr. Ri He from Ningbo Institute of Materials Technology \& Engineering, CAS for scientific discussions about phase conversion mechanism. The help from Prof. Dr. Qiuju Zhang in Ningbo Institute of Materials Technology \& Engineering, CAS, in structure modelling of $\mathrm{Nb}_{2} \mathrm{O}_{5}$ is appreciated. The authors also thank Prof. Dr. Wei Cao from Ningbo University for scientific discussions about the emcoating structure interpretation. This research was supported by the National Key R\&D Program of China (2016YFB0100100), the National Natural Science Foundation of China (51702335 and 21773279), Zhejiang Non-profit Technology Applied Research Program (LGG19B010001), Ningbo Municipal Natural Science Foundation (2018A610084), the CAS-EU S\&T Cooperation Partner Program (174433KYSB20150013), and the Key Laboratory of Bio-based Polymeric Materials of Zhejiang Province. Cheng YJ acknowledges the funding from Marie Sklodowska-Curie Fellowship in EU. Peter G. Bruce is indebted to the Engineering and Physical Sciences Research Council (EPSRC), including the SUPERGEN Energy Storage Hub (EP/L019469/1), Enabling Next Generation Lithium Batteries (EP/M009521/1), Henry Royce Institute for Advanced Materials (EP/R00661X/1, EP/S019367/1, EP/R010145/1) and the Faraday Institution All-Solid-State Batteries with $\mathrm{Li}$ and $\mathrm{Na}$ Anodes (FIRG007, FIRG008) for financial support.

Author contributions Cheng YJ conceived the idea. Ji Q and Wang X designed the experiments and contributed to data analysis. Zuo $\mathrm{X}$ carried out the TEM and Raman tests. Xu Z operated the theoretical calculation and GITT measurements. Gao X designed and performed the DEMS test. The paper was written by Ji Q with support from Cheng YJ. All authors helped in the revision of the paper and contributed to the general discussion.

Conflict of interest The authors declare no conflict of interest.

Supplementary information Supporting data are available in the online version of the paper.

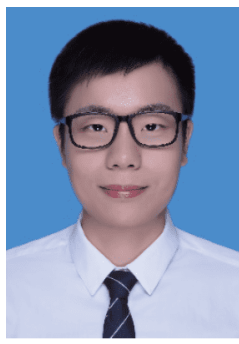

Qing Ji received his BE degree from Beijing University of Chemical Technology (2012). He is a PhD candidate at the University of Nottingham Ningbo China, jointly with Ningbo Institute of Materials Technology and Engineering, Chinese Academy of Sciences (CAS). His research interest focuses on negative electrodes for lithium-ion batteries. 


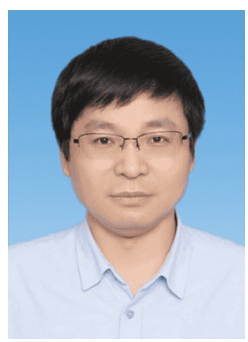

Ya-Jun Cheng is currently a professor at Ningbo Institute of Materials Technology and Engineering, CAS. He received his BSc degree from Peking University, China, followed by a Master degree from the University of Siegen, Germany, and completed $\mathrm{PhD}$ at Max-Planck Institute for Polymer Research in Mainz, Germany. His research interests focus on polymer/inorganic nanohybrids for advanced battery applications.

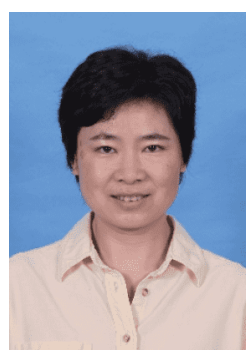

Binjie Hu received her $\mathrm{PhD}$ degree at the University of Newcastle, UK. Then she worked as research fellow and teaching fellow at the University of Birmingham, UK (2000-2006) and University of Cambridge, UK (2007-2010), respectively. She is currently an associate professor of the University of Nottingham Ningbo China. Her research areas include micro/nano-materials engineering and green engineering.

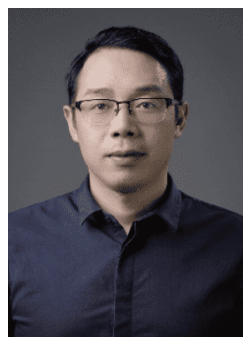

Yonggao Xia received his $\mathrm{PhD}$ in energy and materials science from Saga University, Japan (2008). He is currently a professor at Ningbo Institute of Materials Technology and Engineering, CAS, heading the research group of Novel Organic Electrolyte and Corresponding Devices. His research focuses on advanced materials and technologies for lithium-ion batteries.

\section{通过构筑嵌覆型碳结构提升 $\mathrm{Nb}_{2} \mathrm{O}_{5}$ 的储锂性能}

姬青 ${ }^{1,2 \dagger}$, 徐住军 ${ }^{1,3 \dagger}$, 杲祥文 ${ }^{4,5 \dagger}$, 程亚军 ${ }^{1,4^{*}}$, 王晓艳 ${ }^{1}$, 左秀霞 ${ }^{1}$, 陈政 ${ }^{2,6}$, 胡斌杰 ${ }^{2 *}$, 朱锦 ${ }^{1}$, Peter G. Bruce ${ }^{4,7,8}$, 夏永高 ${ }^{1,9^{*}}$

摘要 嵌入型过渡金属氧化物因具有安全的工作电压、高比容量 和快速的嵌锂能力而受到广泛关注. 但低本征电导率特性严重影 响其作为锂电负极材料的寿命和性能. 本文通过简便易行、可规 模化放大的二氧化碳热处理方法构筑了具有新型嵌覆型碳结构的 $\mathrm{Nb}_{2} \mathrm{O}_{5} / \mathrm{C}$ 纳米杂化材料. 在控制碳含量的前提下, 实现了颗粒聚 集体内部表面可控碳包覆. 以嵌覆型碳结构的 $\mathrm{Nb}_{2} \mathrm{O}_{5} / \mathrm{C}$ 纳米杂化 材料为负极组装的锂离子电池在 $40 \mathrm{~mA} \mathrm{~g}^{-1}$ 电流密度下容量可达 $387 \mathrm{~mA} \mathrm{~h} \mathrm{~g}^{-1}$, 而在 $200 \mathrm{~mA} \mathrm{~g}^{-1}$ 电流密度下循环 500 次后, 容量保持 率在 $92 \%$ 以. 采用电化学滴定、差分电化学质谱(DEMS)等方法 对嵌覆型五氧化二铌/碳纳米杂化材料脱嵌锂动力学过程以及产气 行为进行了研究. 本文提出的嵌覆型碳结构有望为高性能嵌入型 过渡金属氧化物的结构设计提供参考. 